\title{
Forging Responsible Unions: Metal Workers and the Rise of the Labour Injunction in Canada
}

\author{
Eric Tucker \\ Osgoode Hall Law School of York University, etucker@osgoode.yorku.ca \\ Judy Fudge \\ Osgoode Hall Law School of York University \\ Source Publication: \\ Labour/Le Travail. Volume 37 (1996), p. 81-119.
}

Follow this and additional works at: https://digitalcommons.osgoode.yorku.ca/scholarly_works (c) (1) $(9)$

This work is licensed under a Creative Commons Attribution-Noncommercial-No Derivative Works 4.0 License.

\section{Recommended Citation}

Tucker, Eric, and Judy Fudge. "Forging Responsible Unions: Metal Workers and the Rise of the Labour Injunction in Canada." Labour/Le Travail 37 (1996): 81-119.

This Article is brought to you for free and open access by the Faculty Scholarship at Osgoode Digital Commons. It has been accepted for inclusion in Articles \& Book Chapters by an authorized administrator of Osgoode Digital Commons. 


\section{Forging Responsible Unions: Metal Workers and the Rise of the Labour Injunction in Canada}

Eric Tucker and Judy Fudge

\section{Introduction}

THE SUBJECT OF THIS ARTICLE is a series of strikes conducted chiefly by metalworkers in south central Ontario between 1900 and 1914. These strikes are significant because of the novel response to them by employers; they sought and obtained legal injunctions on the grounds that the goals pursued or the means used by the strikers tortiously interfered with their right to conduct business. Damage actions against unions and their officers were also pursued. Courts were sympathetic to these employer claims and the resulting legal interventions placed significant limitations on the scope of lawful trade union activity. These restrictions remain a central part of modern labour law.'

Our purpose, however, is not merely to retrieve the largely forgotten genealogy of current law. Rather, this study is part of a larger project examining the role of law in constituting, maintaining, shaping, and contesting unequal power relations between workers and employers in Canada prior to the advent of statutory collective bargaining schemes during and after World War II. ${ }^{2}$

${ }^{1}$ For example, the massive use of injunctions by Ontario employers in the 1960 s sparked two inquiries. See A.W.R. Carrothers, Reporn of a Study on the Labour Injunctions in Ontario (Toronto 1966) and Ontario, Royal Commission Inquiry into Labour Disputes, Report (Toronto 1968) (Ivan Rand, Commissioner). In response, procedural reforms were enacted in 1970. See The Judicature Amendment Act, 1970 (No. 2), S.O. 1970, c. 91. The substantive common law restrictions on strike activity remain.

${ }^{2}$ For a preliminary sketch of the terrain, see Eric Tucker, "Labour Law and Fragmentation before Statutory Collective Bargaining," in Mercedes Steedman, Peter Suschnigg, and Dieter K. Buse, eds., Hard Lessons (Toronto 1995), 99-116.

Eric Tucker and Judy Fudge, "Forging Responsible Unions: Metal Workers and the Rise of the Labour Injunction in Canada," Labour/Le Travail, 37 (Spring 1996), 81-120. 
A study of labour history through the prism of the law yields important insights on two of the debates raging within the discipline. The first is on the role of institutions and, in particular, the question of their autonomy and the extent to which the well-being of the labour movement is tied to a supportive state. The second is on the role of discourse and, in particular, legal discourse in setting up categories which delimit the realm of legitimate claims, organize those claims in particular ways, and privilege some claims over others.

The debate over the role of institutions and the state has deep roots within the labour movement and among labour historians. Within the labour movement, proponents of voluntarism and syndicalism have struggled with labourists and social democrats over the merits of collective bargaining and direct action, as opposed to electoral politics and direct state regulation. The former tend to see the capitalist state as inherently hostile and believe that labour should strive for a "hands off" policy, while the later hold that workers can make substantial progress through parliamentary reforms. ${ }^{3}$ This debate also has deep resonance between labour historians and is overlaid by disagreements over the independent effects of institutions on class relations.

The writing of labour history is sensitive to the shifting fortunes of the labour movement. The "old" labour historians tended to focus on the development of the institutions of collective bargaining and were often closely associated with industrial pluralists who viewed the achievement of statutory collective bargaining as a progressive outcome of past struggles. Many of these studies were whiggish, portraying law's development as a linear progression from repression to toleration and, eventually, to the promotion of unions and collective bargaining. ${ }^{4}$

The "new" labour historians, rather than celebrating existing labour relations schemes, often viewed them as mechanisms that had coopted unions, making them managers of discontent rather than agents of progressive change challenging an order in which workers interests were subordinated to those of capital. Buoyed by renewed radicalism and rank and file militancy in the 1960 s, these researchers

${ }^{3}$ For discussion of these debates in Canada at the turn of the century, see A. Ross McCormack, Reformers, Rebels, and Revolutionaries (Toronto 1977); Mark Leier, Where the Fraser River Flows (Vancouver 1990); and Craig Heron, "Labourism and the Canadian Working Class," Labour/Le Travail, 13 (1984), 45-76. More generally, see Michael Mann, "Sources of Variation in Working-Class Movements in Twentieth-Century Europe," New Left Review, 212 (1995), 14-54.

For a more complete discussion of this whiggishness, see Judy Fudge, "Voluntarism, Compulsion, and the 'Transformation' of Canadian Labour Law During World War II," in Gregory S. Kealey and Greg Patmore, eds., Canadian and Australian Labour History (Sydney 1900), 81-100. Two scholars who have embraced this position are Antoine Jacobs, "Collective Self-Regulation," in Bob Hepple, ed., The Making of Labour Law in Europe: A Comparative Study of Nine Countries Up to 1945 (London 1986) and Gaston V. Rimlinger, "Labor and the Government: A Comparative Historical Perspective," Joumal of Economic History, 37 (1977), 210-29. 
sought to rediscover an oppositional working-class culture and tradition of resistance on the shop floor and in the streets. In short, they sought to recover the "suppressed alternatives" that failed to become institutionalized."

Since then, there have been calls for a renewed emphasis on and reassessment of industrial relations institutions, including labour law, from a variety of quarters including neo-institutionalists, ${ }^{6}$ regulation theorists, ${ }^{7}$ industrial relations theorists, ${ }^{8}$ and labour and labour law ${ }^{10}$ historians. As in the past, much of this theorizing is stimulated by current events: the declining fortunes of the labour movement and socialist and social democratic political parties. William Forbath and Victoria Hattam, for example, seck to explain the origins of American labour's anti-statism and its impact on the weak institutionalization of class relations in the United States on the basis of a particularly powerful judiciary's hostility to trade unions in the late-19th and early-20th century. " Chris Tomlins, looking at a later period,

${ }^{5}$ Alan Fox, History and Heritage (London 1985), xi.

6For two excellent collections, sec Peter B. Evans et al, eds., Bringing the State Back In (Cambridge 1985) and Sven Steinmo et al, eds., Structuring Politics: Historical Institutions in Comparative Analysis (Cambridge 1992).

'For example, see Alain Lipjetz, Mirages and Miracles: the Crises of Global Fordism (London 1987), ch. 1 and Jane Jenson, "Different' but not 'Exceptional': Canada's Permeable Fordism," Canadian Review of Sociology and Anshropology, 26 (1989), 69-94. ${ }^{8}$ Anthony Fermer and Richard Hyman, "Industrial Relations in the New Europe: Seventeen Types of Ambiguity" in Fermer and Hyman, eds., Industrial Relations in the New Europe (Oxford 1992), xvi-xlix and Wolfgang Streock, "The Uncertainties of Management in the Management of Uncertainty: Employers, Labor Relations, and Industrial Adjustment in the 1980s," Work, Employment \& Society, 1 (1987), 281-308.

${ }^{9} \mathrm{Calls}$ for a renewed focus on institutions have come from a variety of quarters and provoked numerous symposia. A partial list includes: Christopher L. Tomlins. The State and the Unions (Cambridge 1985); David Brody, "Labor History, Industrial Relations, and the Crisis of American Labor," Ind. and Labor Relations Review, 43 (1989), 7-18; Jonathan Zeitlin, "'Rank and Filism' in British Labour History: A Critique," Intermational Review of Social History, 34 (1989), 42-6 (and responses and rejoinder); Howard Kimeldorf, "Bringing Unions Back in (Or Why We Need a New Old Labor History)," Labor History, 32 (1991), 91-103 (and responses); Ira Katznelson, "The 'Bourgeois' Dimension: A Provocation About Institutions, Politics, and the Future of American Labor History," International Labor and Working-Class History, 46 (1994), 7-32 (and responses); and Melvyn Dubofsky, The State and Labor in Modern America (Chapel Hill 1994), esp. xi-xviii.

${ }^{10}$ William E. Forbath, Law and the Shaping of the American Labor Movement (Cambridge 1989) and "Courts, Constitutions, and Labor Politics in England and America: A Study of the Constitutive Power of Law," Law and Social Inquiry, 16 (1991), 1-34; Victoria C. Hattam, Labor Visions and State Power: The Origins of Business Unionism in the United States (Princeton 1993); and Catherine Fisk, "Still 'Learning Something of Legislation': The Judiciary in the History of Labor Law," Law and Social Inquiry, 19 (1994), 151-86 (and responses).

${ }^{11}$ lbid. 
concludes that labour could only expect to win a "counterfeit liberty" from the state. ${ }^{12}$ Melvyn Dubofsky's recent book shares Forbath's, Hattam's, and Tomlins' views on the importance of law and the state in the history of American labour, but assesses its role differently. He finds that American workers benefitted from positive state intervention at particular junctures and concludes that American workers cannot abandon efforts to obtain more favourable legal and administrative arrangements. ${ }^{13}$ Coming from a comparative industrial relations perspective, Anthony Ferner and Richard Hyman argue that the pattern of institutionalization of industrial relations helps explain why some labour movements are faring better than others in the face of structural changes and conjunctural crises. ${ }^{14}$

While we reject the stronger claims made by neo-institutionalists about the autonomy of the state and law, we believe that labour history can benefit from careful studies of relations between labour, law, and the state. Class power is not independent of institutions, but neither are institutions independent of class power. Workers and employers struggle to shape the institutional and legal environment in which their relations will be conducted. Once established, this environment has, to varying degrees, a life of its own that mediates the effect of future shifts in the balance of economic and political power between labour and capital. For example, the interventions by the courts that are the subject of this article have had a limiting effect on trade union activity and effectiveness over the 20th century, despite significant shifts in organized labour's fortunes. Of course, it was not fortuitous that courts adopted a position hostile to collective action by workers. Contrary to the pluralists, we reject the view that institutions like courts (or legislatures) are neutral or that workers and employers can usually be expected to exert countervailing power on or within them.

Ultimately, these debates cannot be resolved theoretically. In our longer study, we hope to provide a fuller analysis of the dynamics of the institutionalization of class relations in law and its effects. Here, our objective is a more limited one. We seek to describe generally the elements of the legal regime that was constructed during a critical period of labour's history and to study, in detail, the emergence of one particular instrument, the labour injunction. Although Canadian courts had been involved in labour disputes earlier because of their criminal law power, ${ }^{15}$ the development of its civil law jurisdiction greatly facilitated the ability of employers to invoke judicial power to limit trade union activity. In addition to its repressive aims, the litigation also aimed at reshaping trade unions as institutions by making them entities legally separate from their members and responsible for their mem-

${ }^{12}$ Tomlins, The State and the Unions, 328.

${ }^{13}$ Dubofsky, The State and Labor, xvi-xvii.

14 Ferner and Hyman, "Industrial Relations," xxxiii.

${ }^{15}$ See Eric Tucker, "'That Indefinite Area of Toleration': Criminal Conspiracy and Trade Unions in Ontario, 1833-1877," Labour/Le Travail, 27 (1991), 14-51 and "The Faces of Coercion: The Legal Regulation of Labor Conflict in Ontario, 1880-1889," Law \& History Review, 12 (1994), 277-339. 
bers' actions. ${ }^{26}$ While the litigation was only partially successful in this regard, the goal of producing "responsible unionism" was pursued through a number of avenues.

A final point that cannot be fully developed here is the degree of complexity and flexibility within institutional arrangements. The concept of institutionalization should not connote simple but rigid structures that yield or only permit uniform responses regardless of the circumstances. Although such arrangements may emerge, they are neither necessary nor normal. The Canadian industrial relations regime during this period was institutionally complex, involving overlapping and uncertain federal and provincial jurisdiction and activity by the legislative, executive, and judicial branches of government, and was capable of very different responses depending on the context. While an overview of this institutional complexity is provided in the following section, we can only begin to suggest the salient factors influencing state and legal responses to a strike. These inchuded, the size of the strike, its significance for the national economy or government revenues, whether or not skilled or unskilled workers were involved, and the political orientation and organizational affiliation of any trade unions involved. ${ }^{17}$

The second debate we engage with is over the role of discourse. Law in particular is often seen as an important site for the production of discourses that, in some readings, are presumed to play an enormously powerful role in shaping human consciousness and behaviour. This "linguistic turn" challenges the materialist and class-based analyses that were common theoretical premises of much of the "old" new labour history. Not surprisingly, the ensuing debate has been sharp. ${ }^{18}$

Again, while rejecting the stronger claims of discourse theory, the ideological role of law merits careful examination. We find it useful to adopt Purvis and Hunt's distinction between discourse and ideology. While both refer to the idea that people's participation in, and understanding of, social life is mediated by communicative practices, discourse refers more to the internal features of those practices and the processes through which they are produced, while ideology is primarily concerned with their external effects. Are discursive practices incorporated into lived experience so as to help perpetuate relations of domination and subordination

${ }^{16}$ This theme has been developed in an American context by Ruth O'Brien, "'Business Unionism' versus 'Responsible' Unionism: Common Law Confusion, the American State, and the Formation of Pre-New Deal Labor Policy," Law and Social Inquiry, 18 (1993), 255.96.

${ }^{17}$ The analysis is more fully developed in Judy Fudge and Eric Tucker, "The Contexts of Coercion: Labour, Law, and the Canadian State, 1900-1914," paper presented at the Sixteenth Annual North American Labor History Conference, Wayne State University, Detroit, Michigan, 27-29 October 1994.

${ }^{18}$ The literature is voluminous. For a sympathetic assessment, see Lenard R. Berlanstein, ed., Rethinking Labor History (Urbana 1993); for a critique, see Bryan D. Palmer, Descent into Discourse (Philadelphia 1990). 
by naturalizing and normalizing them? ${ }^{19}$ From this perspective, law is a particular form of discourse produced through highly stylized, internally rational, and normative arguments that follow rules distinct from those governing ordinary conversation. ${ }^{20}$ It is clear that legal discourse may have some material effects insofar as law's words are implemented and enforced by organs of the state, ${ }^{21}$ but the question here is to what extent, under what circumstances, and on whom does legal discourse have ideological effects?

The last point requires some explanation. Legal discourse is directed at a number of audiences and it is important to consider whether or not it has different effects on different groups. ${ }^{22}$ In our context, for example, we need to consider the ideological effect of law on particular groups of workers (for example, skilled/unskilled), on trade union leaders, on employers, on state officials, and on other members of the public. Moreover, trying to assess ideological effects raises a host of difficult evidentiary and interpretive issues. How do we distinguish between what Terry Eagleton has characterized as "normative" and "pragmatic" acceptance by subaltern groups of a system of rules that characteristically operates to their disadvantage? ? $^{23}$ Thus, while this article considers the ideological effect of the particular body of case law produced by the courts in the cases under consideration, our conclusions remain tentative.

In what follows, then, we first examine the legal infrastructure of industrial relations during this period before turning to our case study. After all, in an institutionally complex and flexible regime, knowing what did not happen is as important as knowing what did. The case study itself allows us to focus on the development of one aspect of a rapidly evolving regime and closely to consider its operation and impact in a particular, but not unusual, context.

${ }^{19}$ Trevor Purvis and Alan Hunt, "Discourse, ideology, discourse, ideology, discourse, ideology ... ," British Journal of Sociology, 44 (1993), 473-99.

${ }^{20}$ Anthony Woodiwiss, Social Theory after Post-Modernism: Rethinking Production, Law, and Class (London 1990).

${ }^{21}$ This point cannot be too strongly emphasized. See Douglas Hay, "Time, Inequality, and Law's Violence," in Austin Sarat and Thomas R. Kearns, eds., Law's Violence (Ann Arbor 1992), 141-73.

${ }^{22}$ Hay, ibid., 169, highlights the need to consider the differential impact of law's coercion and law's word on different audiences:

"The coercive impact of law is the most important element for those who, in fact, are the most direct victims of its violence, the poor; the legitimation of the word is most compelling to those predisposed to believe it, who share in it and articulate it. But that legitimation is crucial, because it enables the coercion to take place."

${ }^{23}$ Terry Eagleton, Ideology (London 1991), 56. Also see Alan Hyde, "The Concept of Legitimation in the Sociology of Law," Wisconsin Law Review, [1983], 379-426. 


\section{Legal Infrastructure}

OUR STARTING PONT in discussing the role of law and its instrumentalities is that, in capitalism, "private" power is constituted and supported by a public infrastructure and that law is an important component of that infrastructure. Private property and market exchange are core instiutions of capitalist regimes, and law is fundamental to their creation, operation, and legitimation. ${ }^{24}$ Directly coercive law played a prominent role in creating "free" labour and in structuring the labour market to the advantage of employers. "The "old" coercion, including master and servant law and criminal conspiracy, compellod workers, under threat of punishment, to perform their contracts and abstain from collective action. Although used more extensively in Great Britain than in Canada through the first three quarters of the 19th century, these laws disciplined Canadian workers, especially during periods of increased labour conflict. ${ }^{20}$ Few employers, however, actively resisted the repeal of the old coercion in the 18703. They sensed, perhaps, that the basic operating principles and norms of the capitalist labour market were strongly institutionalized and that their interests would be protected by the oblique coercion of the market regime, legally constituted by the laws of property and contract.

Our characterization of the labour market as coercive rests on the claim that, despite the formal equality of workers and employers as legal subjects within the market, power was distributed very unequally between workers and employers in a class-divided society. By virtue of their ownership of the means of production and the objects of labour, employers enjoyed a bundle of rights, privileges, powers, and immunities exercisable against non-owners, especially workers. ${ }^{27}$ For the purposes of this article, it is the rights and privileges that are most significant. Employers enjoy a legal privilege when they can choose between various courses

${ }^{24}$ For similar views, see Francis Snyder and Douglas Hay, "Comparisons in the Social History of Law: Labour and Crime," in Frances Snyder and Douglas Hay, eds., Labour, Law, and Crime; An Historical Perspective (London 1987), 1 and Alan Hunt, "On Legal Relations and Economic Relations: A Critique of G.A. Cohen," reprinted in his Explorations in Law and Society (New York 1993), chap. 8.

${ }^{25}$ The significance of the old coercion in the creation of capitalist labour markets has been recognized only recently. For example, see Karen Orren, Belated Feudalism (Cambridge 1991) and Robert J. Steinfeld, The Invention of Free Labor: The Employment Relation in English and American Law and Culture, 1350-1870 (Chapel Hill 1991).

${ }^{26}$ For England, see Daphne Simon, "Master and Servant," in John Saville, ed., Democracy and the Labour Movement, (London 1954), 160-200 and John V. Orth, Combination and Conspiracy: A Legal History of Trade Unionism, 1721-1906 (Oxford 1991). For Canada, see Paul Craven, "The Law of Master and Servant in Mid-Nineteenth Century Ontario," in David Flaherty, ed., Essays in the History of Canadian Law, Vol. 1 (Toronto 1981) 175-211 and Tucker, "That Indefinite Area of Toleration."”

${ }^{27}$ Westey N. Hohfeld, "Some Fundamental Legal Conceptions as Applied in Judicial Reasoning," Yale Law Joumal, 23 (1913), 16-59. 
of action and workers cannot call upon the state to stop them. Employers enjoy a legal right when they can choose between courses of action and can call upon the state to prevent workers from interfering with their choice.

For example, at the very least, employers enjoyed a legal privilege to select and direct their workforces. At common law, employers' freedom to choose with whom to contract allowed them both to discriminate against potential employees on the basis of union membership or activity and to refuse to bargain with their employees other than on an individual basis. If current employees refused to work until their employers met their demands, the employer was at liberty to employ other workers (strikebreakers), often supplied by employment agencies. Private detectives could also be hired to root out union organizers and enforce blacklists. ${ }^{28}$ Workers could not call upon the state to stop employers from doing any of these things. But the question remained: did employers enjoy a right to do these things in the sense that they could call upon the state to stop workers from interfering, in any way or in some ways, with, for example, their attempts to contract with strikebreakers?

The law was not always clear about the scope of employer rights, especially when they were not contested. As long as employers did not aggressively assert their legal privilege to hire strikebreakers, there was no need to determine whether or not this hiring was also a legally protected right. Also, to the extent that workers accepted the hegemony of employer privilege and did not interfere with their liberty, legal rights' claims did not need to be made by employers. Similarly, when employers were confident that market forces would put a stop to trade union interference with privileges, they were less likely to assert legal rights' claims. When, however, confrontations erupted and employer confidence wavered, employers, or their legal advisers, recognized that rights were more powerful than privileges, and that the enjoyment of legal rights depended upon the existence of a legal infrastructure provided by the state which would acknowledge and enforce their rights' claims to be free from interference. This created incentives to retain, create, and resort to directly coercive laws that imposed duties on workers not to interfere at all, or in particular ways, with their employers' actions.

Even after much of the old coercive law had been repealed, criminal law continued to impose some limits on worker interference with employers' freedom of contract. Violence or the threat of violence was no more lawful in the context of strikes than it was elsewhere and, indeed, a Canadian statute passed in 1869 imposed greater penalties for strike-related violence. ${ }^{29}$ Moreover, as the old coer-

${ }^{28}$ In some instances, particularly in mining, the employer also owned the homes and controlled the communities in which workers lived. This gave them extra leverage. Miners who went on strike could be evicted from company-owned housing and debts accrued by them at the company store functioned to restrict their mobility. See, for example, John Mellor, The Company Store (Halifax 1983).

${ }^{29}$ S.C. 1869, c.20, s.42. 
cion was repealed, new offenses were created to limit strike activity. For instance, tactics such as picketing easily ran afoul of the new criminal prohibition against watching and besetting. While the precise contours of the offense were contested, as judges diagreed over whether verbal taunts alone were sufficient or whether the threat of physical force was required, the possibility of conviction and incarceration for watters found to have overstepped the bounds of legality was real. ${ }^{30}$

Limits on lawful atrike activity were not imposed exclusively through the criminal law. The common law, especially the law of tort, played an increasingly important role in the early 20th century as employers, with the active support of judges, began exploiting its more directly coencive possibilities. Employers sought injunctions and brought actions for damages against trade unions and their officers and members for atrike-related activities. The courts held that striking workers were under a legal duty not to interfere with the right of employers to recruit and hire replacement wodtrer. Striking workers were prohibited from inducing other workers to breach their contracts of employment. Judges also declared it to be unlawful for striking workes to organize consumer boycotts or to take action against other employers who continued to do business with the struck employer. Injunctions to stop immediately the workers' offending behaviour could be obtained expeditiously from the courts and workers who violated their terms could be cited for contempt and punished. Damage actions threatened to bankrupt the union and, potentially, some of its members.

Unionized workers resisted these legal claims and were able to limit the effectiveness of employer actions. Some judges were more tolerant of peaceful persuasion than others and the nature of trade unions as legal entities created difficulties in determining the precise legal basis for, and nature of, liability. Political campaigns for legislative redress were less successful, with the exception of British Columbia where legislation was enacted in 1902 giving trade unions immunity from many of the common law liabilities. ${ }^{31}$

Because unlawful and, particularly, violent behaviour were seen to be illegitimate by significant portions of the populace, its presence enabled state officials to justify the use of force. The militia and military, the Royal North West Mounted Police (RNWMP, later to become the Royal Canadian Mounted Police), and provincial and local police, including special constables sworn in for the occasion, were often mobilized in strikes on the ground that they were needed to enforce public onder. In practice, this meant that employers who wished to continue operating during a strike and had the resources to bring in strikebreakers received a great deal of direct state assistance.

As was the case when other coercive forms of law were used, the policing of strikes was contested. Local authorities directly responsible for maintaining civic

${ }^{30}$ Tucker, "That Indefinite Area," 41-51 and Tucker, "The Faces of Coercion."

${ }^{31}$ An Act 10 amend the law relating to Trade Unions, S.B.C. 1902, c.66. Also, see references, infra., note 45. 
order were not always in sympathy with the employer. This was particularly true of elected officials. When, however, local officials did act, they had a number of options. If local forces were inadequate for the task, officials could swear in special constables, but then they might have to pay for their services and could not always count on the professionalism or loyalty of new recruits. Perhaps to avoid such problems, officials sometimes hired men supplied by private detective agencies. ${ }^{32}$ In some jurisdictions, requests could be directed to provincial governments for provincial police, but provincial officials were often hesitant to commit their forces, perhaps because they were concerned about the cost or because they wished to avoid becoming embroiled in local labour disputes unless an emergency situation clearly existed. ${ }^{33}$ In other provinces or territories, requests for additional police would be directed to the RNWMP. Finally, a request to the federal government for the deployment of the militia could be initiated by elected officials or police magistrates. While police magistrates may have had fewer qualms over calling in troops, the financial burden of doing so fell on the municipality. This may have inhibited local officials. Indeed, because of the high incidence of local defaults, after 1904 the federal government began to require municipalities to make a down payment of costs before they agreed to deploy the militia. ${ }^{34}$

Once the police or militia was on the scene, further decisions had to be taken in respect of what actions in support of the strike would be tolerated and how the police would achieve their objectives. Certainly, the employers' property and strikebreakers would be protected from violence, but the extent to which other actions in support of the strike would be permitted and more repressive police measures would be taken depended on a variety of circumstances. One conclusion, however, is clear. Canadian police and militia used lethal force far less frequently than their American counterparts. ${ }^{33}$

${ }^{32}$ For example, during the 1907 strike by silver miners in Cobalt, ON, local officials swore in special constables recruited locally and supplied by the Canadian Detective Bureau. The Ontario government paid for the private detectives. See Ontario Archives (OA), RG 4-32, file 1907/996. In some instances, mine owners paid for specials. For example, see OA, RG 4-32, file 1914/179. More research is required on who underwrote the costs of policing strikes.

${ }^{33}$ For example, in Ontario, requests from local officials for provincial police assistance in strikes were commonly resisted both by the Attomey-General's department and by Joseph Rogers, the first Superintendent of the Ontario Provincial Police (established by order-incouncil in 1909). For a discussion of the role of the British Columbia Provincial Police in this area, see Lynne Stonier-Newman, Policing a Pioneer Province (Madeira Park, BC 1991), 75-76, 81-81, and 98-107.

${ }^{34}$ Desmond Morton, "Aid to Civil Power: The Canadian Militia in Support of Social Order. 1867-1914," Canadian Historical Review, 51 (1970), 407-25, at 422.

${ }^{35}$ For a particularly useful discussion of policing issues, see William M. Baker, "The Miners and the Mounties: The Royal North West Mounted Police and the 1906 Lethbridge Strike," Labour/Le Travail, 27 (1991), 55-96. Despite its failure to properly emphasize the role of 
One further way the state directly intervened to shape the market to favour employers was through immigration law. Constituting a labour market in Canada required immigration and the state played an active role in recruiting workers, mostly from Britain. Employers had an active interest in promoting high levels of immigration to create a well-stocked, competitive labour market to hold down wage demands and to provide a pool of replacement workers in the event of a strike.

Workers understood the significance of immigration policy for their labour market position and opposed active state recruitment policies, generally with little success. However, when the United States limited the ability of Canadian workers to obtain employment in its territory, Parliament was eventually persuaded to pass retaliatory legislation in 1897 . The Alien Labour Act prohibited the importation of foreign workers under contract from countries which placed similar restrictions on Canadian workers. Although the legislation was not passed to protect striking Canadian workers from having their jobs taken by imported American strikebreakers, it would have this effect if enforced. This protective potential, however, was not realized. Despite the efforts of organized labour, few employers were prosecuted for violations of the Act. Moreover, the employers' privilege to contract with strikebreakers from the United Kingdom was unimpaired, as was their privilege and right to contract with other workers presently in Canada. ${ }^{36}$

Immigration law, in addition to limiting or expanding the number of available workers, was also used for directly political purposes. The law was amended in 1906, 1910, and 1919 to enhance the power of the Department of Immigration to prevent foreign organizers and agitators from entering the country and to deport resident aliens who were deemed to have become undesirable because of their radical political activities in Canada. These powers were exercised more frequently, however, after the period we are concerned with here. ${ }^{37}$

The oblique coercion of market-constituting and market-shaping law and the direct coercion of exclusions and deportations, injunctions, criminal prosecutions, and police and the militia did not exhaust the role of law in respect of relations between workers and employers. Facilitative law and, to a lesser extent, protective law also played increasingly important roles. ${ }^{38}$

state violence, a useful description of American labour violence is Philip Taft and Philip Ross, "American Labor Violence: Its Causes, Character, and Outcome," in Hugh Davis Graham and Ted Robert Gurr, eds., Violence in American: Historical and Comparative Perspectives, Vol. 1, (Washington 1969), 221-301.

36. The background to and early operation of the Alien Labour Act is discussed in Eric Tucker, "Suspended Between Two Worlds: Law and Strikes in Ontario, 1890-1900," (unpublished manuscript, 1993). For a more general discussion of immigration and labour, see Donald Avery, Dangerous Foreigners (Toronto 1979).

${ }^{37}$ On deportations, see Barbara Roberts, Whence They Came (Ottawa 1988).

${ }^{38}$ Prior to 1914, the most common form of protective legislation addressed dangerous work conditions, especially for women and children, and the consequences of disabling work-related injuries. Other forms of minimum standards legislation such as minimum wages for 


\section{LABOURRE TRAVAIL}

State interest in the creation of mechanisms to facilitate the resolution of labour disputes through various forms of state-sponsored mediation, conciliation, or arbitration was first expressed legislatively at the same time the "old" coercion was being repealed. A trade dispute arbitration scheme was enacted in Ontario in 1873. but was completely moribund. In the last two decades of the 19th century, Nova Scotia, British Columbia, and Ontario enacted further measures using somewhat different approaches, but none of them gained widespread acceptance. ${ }^{39}$

Although the federal government first became involved in mediating strikes toward the end of the 19th century on an ad hoc basis, it was only in 1900 that it created a statutory framework and permanent institutional structure through which it could act. The Conciliation Act, passed in 1900, not only allowed for voluntary creation of conciliation boards, but also allowed cabinet to appoint a commissioner to hold an inquiry and established a Department of Labour responsible for the collection and publication of labour statistics and information in the Labour Gazette. ${ }^{40}$ This was later followed by the Railway Labour Disputes Act in 1903 and the Industrial Disputes Investigation Act (IDIA) in 1907 which became the centrepiece of Canadian labour law until World War I. ${ }^{41}$

The IDIA was justified on the ground that in industries crucial to the national economic policy, coal included, private rights should give way to the public

women came later. The role of protective legislation is not considered in this article. For an overview, see Margaret McCallum, "Regulating the Employment Relationship: 18671920," University of Manitoba, Canadian Legal History Project, Working Paper Series. $92-8$.

${ }^{39}$ On the first Ontario scheme, see Margaret E. McCallum, "Labour and Arbitration in the Mowat Era," Canadian Journal of Law and Society, 6 (1991), 65-90. On the others, see Margaret McCallum. "The Mines Arbitration Act, 1888: Compulsory Astitration in Context," in Philip Girand \& Jim Phillips, eds., Essays in the History of Canadian Law, Vol. III, Nova Scotia (Toronto 1990), 303-25 and Tucker, "Between Two Worlds." Some provinces, including British Columbia and Ontario, also became involved in the collection of labour statistics in the 19th century. For a general overview, see W: Steward Martin, "A Study of Legislation Designed to Foster Industrial Peace in the Common Law Jurisdictions of Canada," PhD Thesis, University of Toronto, 1954.

${ }^{40}$ Conciliation Act, S.C. 1900, c.24. On the origins and operation of this scheme, see Jeremy Webber, "Compelling Compromise: Canada Chooses Conciliation over Arbitration, 1900 1907," Labour/he Travail, 28 (1991), 15-57; and Bob Russell, Back to Work? (Scarborough 1990).

${ }^{41}$ The literature on the creation of these federal schemes is voluminous. Paul Craven, 'An Impartial Umpire': Industrial Relations and the Canadian State 1900-1911 (Toronto 1980) and Webber, "Compelling Compromise," contain the best discussions. Provincial governments also created similar mechanisms in the period under study. For example, bureaus of labour with responsibility for gathering statistics in respect of labour disputes were created in Ontario (1900), New Brunswick (1904), Quebec (1905), and Saskatchewan (1910). Provincial conciliation and arbitration legislation was enacted in Quebec (1901), Nova Scotia (1903), and Ontario (1906). 
interest. The legislation established a mechaniam for appointing conciliation boards to investigate a dispute, attempt to settle it, and issue a report. These reports served to provide a template of legitimate demands against which the parties' behaviour could be measured. Union demands for a closed shop were considered illegitimate, but so too were claims by employers that they had a right to dismiss employees because of trade union membership. Disputes over union recognition were regarded as perticularly unsusceptible to settlement, and conciliation board reports often urged unions to compromise on this issue. On occasion, board reports also condemned specific unions, invoking the fear of foreign agitators in doing so. ${ }^{42}$ While these reports may have provided ammunition to the parties, their ideological effectiveness is questionable, as "illegitimate" demands continued to be regularly made by the parties to disputes.

The IDIA's effect, however, was not excluaively ideological and facilitative, nor was it meant to be. The legislation provided access to criminal sanctions in the event that anyone violated the ban on the use of economic weapons until after the conciliation boand had issued its report. Violators were liable to be incarcerated. What is significant about the enforcement of these sanctions is that the federal government explicitly abstained from prosecuting violations of the IDIA and, essentially, delegated the initiation of its criminal law power to the parties. When employers prosecuted union organizers for calling and supporting strikes in violation of the Act, the courts read the statutory restrictions broadly. Union officials were convicted for participating in strikes where neither party had invoked the Act and for providing food and other benefits to miners striking in violation of it. The deterence of untimely action largely benefited employers by giving them additional time to organize strikebreakers.

42 Jeremy Webber, "Standards of Industrial Justice: Ideology and the Reports of Conciliation Boards Under the Industrial Disputes Investigation Act, 1907-1925," LLM Thesis, York University, 1988, 173-188. For a seminal articulation of this model of responsible unionism. see Canada, Royal Commission on Industrial Disputes in the Province of British Columbia, Repor, Sessional Papers, "36a (1903). Its background is discussed in Craven, Impartial Umpire, 247-52.

${ }^{43}$ It did not take long for the coercive component of the IDIA to be invoked. Silver miners in Cobalt, Ontario, organized by the Western Federation of Miners, struck in July 1907. Even though neither party had invoked the Act, the courts upheld the conviction of James McGuire for unlawfully inciting the employees of the Nipissing Mining Company to go on strike. He was fined $\mathbf{\$ 0 0}$ and sentenced to six months imprisonment in default of payment. The penalty was reduced to three months on appeal. After the conviction was upheld the employer proceeded with private prosecutions against three other strike leaders. Rex $\mathrm{v}$. McGuire (1908), 16 O.L.R. 522 (D.C.) and OA. RG 4-32, Files 1907/969 and 1907/1393. On the prosecution of trade unionists for providing support to illegal strikers, see Report of the Deputy Minister of Labour on Industrial Conditions in the Coal Fields of Nova Scotia, Sessional Paper. No. 36a (1909), 21-2 and The King v. Neilson, (1910), 17 C.C.C. 298. 
In sum, inchustrial relations were institutionalized through a wide array of legal instruments, administered by judges and other state officials, that could serve a variety of purposes. At its core was a capitalist labour market, constituted and shaped by law. But, the system was flexible and provided employers and state officials with a wide range of options in the event of labour conflicts. The level and kinds of direct and indirect coercion varied, as did the extent and nature of facilitative interventions. Of course, resort to legal devices in labour disputes was not a one-way street, but union traffic was much lighter. Much of the unions' engagement with law was defensive. They resisted extravagant rights' claims of employers in an attempt to preserve some scope for trade union activity; that is, they defended their own privileges and freedom.

In the following case study, we closely examine the development of one aspect of the legal regime, the labour injunction, and its use and effect in one particular context, skilled metal workers employed in large firms. The legal response to these strikes was not "typical." For example, strikes by coal and metal miners frequently were subject to "compulsory conciliation" under the IDIA and direct state repression through the massive deployment of police and militia, responses that were not seen in the strikes that are the subject of this article. ${ }^{44}$ Yet, they were important arenas of struggle over the institutionalization of class relations and their representation in legal and public discourse.

\section{Skilled Metal Workers and the Law of Picketing and Boycotts}

DURING THE SECOND INDUSTRIAL REVOLUTION, employers challenged the working conditions, labour process control, and organizational solidarity of craft workers. Inevitably, this produced strikes and lockouts as workers resisted employers' efforts to reshape production. Of particular interest is the conflict that erupted between the metal workers of southern Ontario and large employers, for it was in this crucible that Canadian employers experimented with legal actions for injunctions and damages as a response to picketing and boycotts, the two major strike weapons of skilled workers. ${ }^{45}$ But the metal workers' tradition of solidarity and

The comparison is more fully developed in Fudge and Tucker, "The Contexts of Coercion."

${ }^{45}$ For a good overview of the context of strikes of the skilled during this period, see Craig Heron and Bryan D. Palmer. "Through the Prism of the Strike: Industrial Conflict in Southern Ontario, 1901-14," Canadian Historical Review, 58 (1977), 423-58. To be sure, injunctions were not used exclusively by employers of skilled labour. The earliest reported case of a labour injunction involved an action by the LeRoi Mining $\mathrm{Co}_{\text {. against the Western }}$ Federation of Miners at Rossland, British Columbia. That litigation raised many of the same legal questions that were crucial to the injunctions against metal workers in Ontario. The major difference between injunctions in mining strikes and those involving skilled industrial workers was the context in which they were applied. Mining strikes typically involved both large numbers of strikers and strikebreakers and, as a result, policing played a more 
organization, and the continued demand for their skills, left them in a better position to contest their employers' initiatives than many other workers. This context shaped the strategies and tactics, both legal and other, of the employers and the unions in their struggles.

The metal trades included a minority of highly skilled workers (eg. pattern makers, moulders, and machinists) and much greater numbers of semi-skilled workers (eg. polishers and stovemounters) and unskilled labourers. For the most skilled, craft unionism had deep roots and the ideals of worker autonomy and control were strongly held and maintained in practice. During the 19th century, for example, conflicts enupted regularly when employers attempted to force moulders to take on more apprentices than their rules allowed or to work with unskilled 'bucks' or with non-union moulders. In Toronto, the moulders emerged victorious more often than not, even though a number of their employers - and especially Edward Gurney - invoked the criminal law in the course of some disputes. Throughout much of this period, the moulders maintained a high level of solidarity, not just with other moulders but with other, less skilled, metal trades' workers. For example, in 1887 the Ontario branches of the International Moulders Union (IMU) formed a district union to coordinate their activities. In 1887 when Gurney locked out moulders in Toronto, moulders at his Hamilton works walked out in sympathy and, a year earlier, moulders at the Massey agricultural implements works in Toronto put down their tools in support of striking labourers organized by the Knights of Labor. The economic downturn which lasted from the late 1880 s to the mid-1890s, however, provided Gurney and Massey with the opportunity to successfully attack the IMU, resulting in a number of protracted strikes and lockouts in the early $1890 \mathrm{~s}^{46}$

Their victory, however, was short-lived. The IMU regained strength with the return of industrial prosperity and the number of metal-based union locals in southern Ontario increased from 16 in 1896 to 75 in 1902 . More generally, trade union organization, most of it associated with American internationals, reached unprecedented levels during these years. A high level of cross-craft solidarity was achieved within the metal trades and sympathy strikes became common. In Toronto

prominent role. On Rossland, see A.W.R. Carrothers, "A Legislative History of the B.C. Trade-unions Act: The Rossland Miners' Case," U.B.C. Legal Notes, 2 (1956), 339-46; A. Ross McCormack, Reformers, Rebels, and Revolutionaries: The Western Canadian Radical Movement 1899.1919 (Toronto 1977), 37-40; Craven, Impartial Umpire, 244-5; Jeremy Mouat, "The Genesis of Westem Exceptionalism: British Columbia's Hardrock Miners, 1895-1903," Canadian Historical Review, 81 (1990), 317-45 and Michael Ripmeester, "Mines, Homes, and Halls: Place and Identity as a Gold Miner in Rossland, British Columbia, 1898-1901," Canadian Geographer, 38 (1994), 98-110.

${ }^{46}$ Gregory S. Kealey, Toronto Worters Respond to Industrial Capitalism 1867-1892 (Toronto 1980), 64-82, 198. 
a federated metal trades council was formed in 1901 to coordinate the activities of the various trades. ${ }^{47}$

Employers, especially large ones, did not sit back and passively watch these developments. The expansion of the economy created new opportunities for profit but, to take full advantage of them, many industrial employers felt the need to loosen the constraints skilled workers placed upon them. In particular, their high cost, control of production, and independence were seen as obstacles to be overcome. Employers sought to do so by reducing the need for skilled workers in production and by attacking their organizational strength. ${ }^{48}$ Employers also understood the need for cooperation among themselves and established both continental and local organizations to assist them in pursuing their common objectives. The National Founders Association (NFA), for example, was formed in 1898 and, although it worked amicably with the IMU nationally during its first years, locally conflict remained high. Employers in Toronto formed an association in 1902 to assist members facing labour trouble. Their leaders included W.H. Carrick of the Gurney foundry and Frank Polson, also a well-known local foundry owner. ${ }^{49}$

In short, at the turn of the century, well-organized workers, aided by a tight labour market, confronted organized employers committed to expanding their control over the labour process. In retrospect, it is not surprising that, when a wave of strikes swept through the metal industry, employers sought to re-shape the terrain on which such conflicts would be conducted. Resort to civil law was one part of this campaign.

The first strike erupted when Massey-Harris introduced moulding machines into its Toronto factory. The union demanded that the machines be placed under

${ }^{47}$ Wayne Roberts, "Toronto Metal Workers and the Second Industrial Revolution, 1889. 1914," Labour/Le Travail, 6 (1980), 49-72. On the growth of the international unions in Canada, see Robert H. Babcock, Gompers in Canada: A Study of American Continentalism before the First World War (Toronto 1974), 38-54 and for a general history of the IMU, see Frank T. Stockton, The Intermational Moulders Union of North America (Johns Hopkins University Studies in Historical and Political Science, Series XXXIX, No. 3) (Baltimore, 1921).

${ }^{48}$ For an overview of developments, see Craig Heron, "The Second Industrial Revolution in Canada, 1890-1930," in Deian Hopkin and Gregory Kealey, eds., Class, Community, and the Labour Movement: Wales and Canada 1850-1930 (Wales 1989), 48-66. On metal workers, see Roberts, "Toronto Metal Workers" and David Rosner and Gerald Markowitz, Deadly Dust (Princeton 1991), 49-62.

${ }^{49}$ Continental associations of foundry owners had formed during earlier periods of conflict. Clarence E. Bonnett, History of Employers' Associations in the United States (New York 1956). On the formation of the NFA, see Clanence E. Bonnett. Employers' Associations in the United States (New York 1922), 66-71. References to the involvement of Canadian employers in the NFA and its predocessors can be found in Kealey, Toronto Workers, 66, 68, \& 74 and Roberts, "Toronto Metal Workers." For a brief history of the Toronto Employers' Association (TEA), see Industrial Canada (IC), October 1907, 220; Heron \& Palmer, "Prism," 448-9; and Michael Bliss, A Living Profit, (Toronto 1974), 93-4. 
its jurisdiction and, when management refued, 80 to 90 moulders, members of IMU Local 28, struck on 3 Februry 1900. Seventeen days later, 45 moulders, members of MMU Local 29 at Massey's Brantford works, went out in sympathy. The Brantford Laborers Protective Union, Local 7370 of the American Federation of Labor, also struck, although it is unclear how many employees of Massey were members.

The tactics employed by the strikers at both locations were the traditional ones. Pickets were sent to watch the factory, neighbourhood, and railway stations. Their objective was to intercept men working as moulders during the strike or potential recruits and persuade them not work. Their means of persuasion varied, ranging from appeals to solidarity, offers to provide assistance in finding work elsewhere, monetary payments, verbal abuse, and physical intimidation. It is important to note, however, that mass picketing and confrontations between large groups of strikers and replacements was not a feature of these strikes. Moulders made up only a tiny fraction of the workforce ( 80 out of 1200 workers in Mnsecy's Toronto factory and 45 out of 700 in Brantford) and so the number of striking and replacement workers was relatively small. Moreover, most strikers did not remain on the scene for long because the union, which paid a strike benefit, encouraged them to find work elsewhere. Only a few workers, generally union officers and strike leaders, kept up strike activities.

At this time, the boundaries of lawful strike activity were defined almost exclusively through the criminal law. Under the Criminal Code, it was an offence for a person to "wrongfully and without legal authority, with a view to compel any other person to abstain from doing anything which he has a lawful right to do ...," use violence, intimidate, persistently follow or watch and beset. Prior to the codification of Canadian criminal law in 1892, the applicable statute was modelled on English law and stipulated that peaceful communication of information did not constitute watching and besetting. For reasons that have not been fully explained, this proviso was removed when the Code was enacted. Thus, while it was clear that physical assaults and intimidation were criminal, the limits on verbal persuasion were less certain. Some judicial pronouncements in prosecutions under the Code in the 1890 s suggested that the omission of the peaceful communication exemption made all forms of picketing criminal watching and besetting, but this interpretation was not generally accepted. ${ }^{\text {so }}$

If Massey had followed past practice, striking workers who participated in more aggressive forms of picketing would have been charged with criminal offenses. Where minor offenses were involved, strikers would have been tried summarily before local magistrates who, very likely, would have convicted them but only imposed nominal fines and warned that future offenders would be treated much more harshly. More serious charges would be tried before a jury, weeks or months after the arrest. Massey, however, adopted a different legal strategy, one

so Tucker, "Between Two Worlds." 
which had been attempted only one other time in Canada, seventeen years earlier, and then forgotten. ${ }^{51}$ It commenced civil legal actions in superior courts against named workers and the local unions involved, seeking injunctions and damages. ${ }^{52}$

The immediate inspiration for this new approach came from England. In the early 1890 s, English judges began to fashion new economic torts designed to protect employers against the kinds of harm that strikes aimed to cause. Interferences with existing contracts or with the formation of future contracts were held to be actionable wrongs without any defence of justification. Picketing to persuade non-striking workers to leave or potential recruits not to take up employment, even when not accompanied by violence or the threat of violence, was also found to be tortious. Taken at its strongest, the effect of these judgements was to render wrongful almost any communication between strikers and current or potential strikebreakers. Moreover, the cases made it clear that interlocutory injunctions could be issued whenever a prima facie case of illegality was made out and grave damage to the employer was threatened. No longer, it seemed, did the plaintiff have to establish there would be damage to property; alternatively, the right to trade was treated as a property interest. In short, interim injunctions seemed to be issued whenever the balance of convenience favoured them and, for most judges, the balance of convenience clearly tilted in favour of allowing the employer to continue operations with as little hindrance as possible. ${ }^{53}$

The Massey actions were modelled on a reading of the English case law as it stood at the time. Not only did Massey seek to prohibit molestation and intimidation; it also wanted to prohibit any attempt, verbal or otherwise, to dissuade employees or would-be employees from continuing or taking up employment. The affidavits filed in support of the applications for ex parte injunctions referred to pickets intercepting strikebreakers and potential strikebreakers with the result that they either left or did not take up employment with the company. Allegations of

${ }^{51}$ Hynes v. Fisher et al. (1883), 4 O.R. 60, discussed extensively in Tucker, "The Faces of Coercion," 284-95.

52 The power to issue injunctions was exercised exclusively by superior court judges.

${ }^{53}$ The literature on the English law is voluminous. For an introduction, see A.W.J. Thompson, "The Injunction in Trade Disputes in Britain before 1910," Industrial and Labour Relations Review, 19 (1965-66), 213-23; J. Saville, "Trade Unions and Free Labour. The Background to the Taff Vale Decision," in M.W. Flynn and T.C. Smout, eds., Essays in Social History (Oxford 1974), 251-76; and Michael J. Klarman. "The Judges Versus the Unions: The Development of British Labor Law, 1867-1913," Virginia Law Review, 75 (1989), 1487-1602. The application of the balance of convenience approach to the benefit of employers is clearly seen in Small v. American Federation of Musicians (1903), 2 O.W.R. 33. In that case, Chancellor Boyd continued an injunction against the union until trial, commenting (at 34): "it is more convenient in the interests of the plaintiff to have the present orchestra continued in his employment till the trial than to have any interruption or discontinuance by the active intervention of the defendants; and this course will be in no wise [sic] detrimental to defendants ...." 
intimidation were made, but little evidence was offered in the affidavits to support the claim. As well, the affidavits emphasized that Massey stood to lose a great deal if its moulding departments were unable to operate while the defendants stood to lose nothing if the injunction was granted. ${ }^{34}$

The process was an expeditious one that worked in favour of the employer. Broadly worded injunctions were granted by the court on the day the action was commenced, solely on the basis of the affidavits filed by Massey. ${ }^{35}$ Examinations of the defendants under oath followed, and this gave Massey the opportunity to explore the internal operations of the union. When some union officers refused to answer questions, ostensibly because they feared criminal prosecution, lawyers for Massey sought to have them jailed for contempt, but their motion was refused when the defendants indicated they would answer questions if directed to do so by the court. The injunctions were continued while the legal wrangling draged on, and no juries were involved in these interlocutory proceedings.

Beyond the substantive limits on strike tactics, the case raised important questions about the legal status of trade unions: did they have a legal personality distinct from that of their members so that they could be parties to legal proceedings in their own name and could trade union funds ultimately be seized in the event damages were awarded? At the time of the Massey actions, the issue had not been settled, but the predominant understanding was that unions were not suable entities. ${ }^{56}$ Not surprisingly, then, solicitors for the union brought a motion to have it struck from the list of defendants. Further affidavits and examinations followed. Argument was heard by Mr. Justice R.M. Meredith on 7 Manch 1900 both on the question of trade union status and on whether or not the injunctions should be continued until trial which would be months away. G.H. Watson Q.C. appeared for Massey-Harris. ${ }^{57}$ He argued that the union and its officers should be held liable for any unlawful actions of its members because, he alleged, it was a corporate body and was engaged in a conspiracy to interfere with the company's employees. E.F.B. Johnson Q.C. appeared for the union and other defendants. He denied the existence of a conspiracy and asserted that the decision to strike had been made by the men employed by Massey, not the union. To the extent that individuals had committed unlawful acts, Johnson conceded that the injunction should continue as against them personally but, he argued, neither the trade union nor its officers could be held liable for those actions. Moreover, he established, apparently to the court's ${ }^{54}$ See OA, RG 22, York County SCO, Action File 201/1900 (Massey v. Woodward et al.) and Action File 214/1900 (Massey v. Lavis et al.). (Hereafter all court files will be cited to Action File \# only).

3s The scope of the writs does not appear to have been quite as far reaching as what was requested. Globe (Toronto), 24 February 1900, 26, col.3.

${ }^{56}$ Taff Vale Railway Co. v. Amalgamated Society of Railway Servants [1901] A.C. 436, the most important case on the issue, was still working its way through the lower courts.

${ }^{57}$ G.H. Watson was a senior member of the bar with a large commerical practice. See Henry James Morgan, ed., Canadian Men and Women of the Time, 2d ed., (Toronto 1912). 
satisfaction, that the union was neither incorporated nor registered and, therefore, had no legal existence. Judge R.M. Meredith reserved judgement. ${ }^{58}$ Two weeks later, he issued his decision. Meredith held that if the acts complained of were committed by the defendants they violated the Criminal Code. The evidence established a prima facie case that organized means were adopted to interfere with the employees. The injunction, therefore, was continued. He also found that, prima facie, the Iron Moulders Union "has some legal existence" so that it could be made a party to the case, although the matter would be dealt with at trial. ${ }^{59}$

The injunctions did not end either strike immediately, but the responses to it differed sharply in Toronto and Brantford. In Toronto there were no further reports of interference by strikers or legal action on the part of Massey. Indeed, in November a motion was brought by Massey to stay the proceedings on the ground that the subject matter of the dispute ceased to exist as all striking moulders were employed elsewhere. ${ }^{60}$ Events in Brantford followed a different course. Strikers persisted in attempting to dissuade strikebreakers and recnuts from continuing or taking employment. This produced three motions to commit strikers to gaol for breaching the injunction, a flurry of affidavits, and hundreds of pages of transcripts of cross-examinations on the affidavits. In respect of two of these motions, consent agreements were reached to defer the matter to the trial of the action upon the defendants undertaking that there would be no further breaches. ${ }^{61}$ On the other motion, oral argument to commit began but ran into difficulty. The evidence indicated that, while strike leaders continued to communicate with potential recruits, there was no intimidation. Chief Justice William Ralph Meredith (older brother of Judge R.M. Meredith) indicated his lack of sympathy with the interpretation of the scope of the restraint being asserted by Massey.

Surely the injunction does not prevent the strikers from doing that. If so, liberty is at an end in this country. I would not commit the men for that. They have a perfect right to expostulate with, but not intimidate, any persons coming to take their places. Have men not a right to tell others of the oppressive treatment of any company, and thus induce them not to enter its employ? ${ }^{62}$

Watson, the lawyer for the plaintiff, referred to recent English cases to support his claim that even this communication was prohibited, and argued that Judge R.M. Meredith had relied upon these precedents in his earlier decision. Argument on the motion was adjourned and no decision ever issued. Ultimately, Massey discontin-

${ }^{58}$ Globe, 8 March 1900, 4, col.2-3.

${ }^{59}$ Globe, 21 March 1900, 5, col.2.

${ }^{60}$ The motion was denied (Globe, 16 November 1900, 7, col.1-2) and costs were awarded to the defendants in any event. The court file contains no documents beyond this motion, suggesting that the matuer was settled or dropped.

${ }^{61}$ Globe, 1 June 1900, 7, col.3 and 28 November 1900, 5, col.1.

${ }^{62}$ Globe, 11 July 1900. 
ved its action as against the two trade unions and, after pleadings were filed and the case against the named individuals was set down for trial, the parties settled out of court in April 1901. ${ }^{63}$

Thus, at the end of the day, neither the legal status of trade unions nor the precise limits on the privileges of strikers had been realved by the Massey actions. There was no unanimity on these issues, even between these brother judges. William Ralph, long known as a friend of the workingman, wanted to preserve some scope for peaceful communication, while his brother Richard Martin, was keen to impose extremely tight restrictions on strike-related activity. He was of the view that all picketing involved an aspect of compulsion and, thus, was enjoinable. ${ }^{64}$ Despite the unsettled state of the law, a new weapon had been added to the employers' arsenal. Employers could obtain, summarily, count onders prohibiting strike activity that previously had been generally considered lawful and, even though the precise restrictions were uncertin, strikers could be kept on the defensive. Contacts between strikers and replecement workers or potential recruits had to be handled more delicately than they had been in the past. ${ }^{60}$ Moreover, the activities of the Brantford strikers were closely monitored by Massey. It documented every arguable breach of the injunction with affidavits and filed motions to commit for contempt which entitled its lawyers to examine, at length, the alleged violators under oath.

${ }^{63}$ Brantford Courter, 9 April 1901, 1, col.3.

William Ralph Meredith was leader of the conservative opposition in Ontario through much of the Mowat era. Nevertheless, he maintained close ties with the labour movement and actively aupported a number of their causes including universal male suffrage and reform of employers' liability law. He is, perhapa, best known for his role in the creation of modern workers' compensation systems. See R.C.B. Risk, "This Nuisance of Litigation': The Origins of Workers' Compensation in Ontario," in David Flaherty, ed., Essays in the History of Canadian Law, Vol. 1, (Toronto 1983), 418-91. Richard Martin Meredith was appointed to the bench out of practice and consistently took the employers side in labour injunction and employer liability casea. Kirt Stevens, "The Ontario Courts and Employers' Liability, 1900-1913," unpublished Osgoode Hall Law Sctool seminar paper, 1984, on file with authors. The stricter interpretation subsequently received support from Mathers in Cotter v. Osborne (1908), 8 W.L.R. 451 (Man. S.C.), upheld in (1909), 18 Man. R. 471 (C.A.), and in Vulcan Iron Worts Co. v. Winnipeg Lodge, No. 174, Ironmoulders Union (1909), 10 W.L.R. 421, upheld in (1911), 16 W.L.R. 649 (Man. C.A.) (picketing held to be a common law nuisance). Also, see the decision of R.M. Meredith in Krug Fumiture Co. v. Berlin Union of Amalgamated Woodworters (1903), 5 O.L.R. 463.

${ }^{65}$ The legality of another common trade union tactic to discourage replacement workers placing ads in newspapers calling upon other members of their craft to keep away because of a strike - was also attacked. When this tactic was used in a strike against the John Dixon Carriage Works in Toronto, the Toronto Employers Association intervenod and all the newspapers involved, except the Globe, agreed to withdraw the warning and not to accept future ones. An interim injunction was obtnined to compel the Globe to refrain from publishing the notice. IC, December 1905, 288-9. 
In addition to these immediate and instrumental advantages, Massey made progress on the ideological front by portraying the unions as bodies that interfered with the rights of other workers to sell their labour freely. Although the strikers and trade union officials were partially successful in resisting this image by asserting their liberal right to free speech, they were unable to put their employer into a defensive posture by painting a picture of Massey as a dangerous tyrant. Thus, while the law did not fully embrace and inscribe the employers' ideal of a "free" labour market, it provided employers with additional leverage, material and moral, in their struggle to restrict and delegitimate strike activity.

In addition to civil actions, employers of skilled labour developed two other techniques to minimize the effectiveness of traditional strike tactics. They improved their organizational capacity to break strikes and sought to have the criminal law regarding picketing more strictly applied.

The impact of improved employer organization on strikes in the metal trades can be seen most clearly in the dispute at Canada Foundry that erupted in June 1903. This strike was part of a larger campaign for a nine-hour day, involving 275 moulders at 11 Toronto firms. ${ }^{67}$ Most of the smaller shops had conceded earlier, but Canada Foundry, with support and guidance from the NFA and the TEA, led the larger firms in resisting the moulders' demands.

Canada Foundry obtained professional scab moulders from the NFA, which kept a number of moulders under yearly contract precisely for this purpose. ${ }^{68}$ Of course, importing moulders from the United States under contract violated the Alien Labour Act, but this would not have deterred Canada Foundry since the Act was weakly enforced. ${ }^{69}$ Another 90 or so moulders who had been hired in Scotland and Britain, allegedly with government assistance and without being told of the strike, arrived in Toronto in July. Another 80 followed later. ${ }^{70}$ Canada Foundry hired Noble's Dominion Detective Agency to provide security and to monitor the IMU's activities, possibly even planting a detective in the union. They also hired James

${ }^{66}$ On the employers' use of the imagery of the free labour market and free labourers, see Ian McKay, "Strikes in the Maritimes, 1901-1914," Acadiensis, 13 (1983), 3-46 and Saville, "Trade Unions."

${ }^{67}$ Roberts, "Toronto Metal Workers," 67.

${ }^{68}$ The discussion generally draws on the material in Canada Foundry v. Emmett et al. Action File 860/1903. On the strikebreaking tactics of the NFA, see Bonneth. Employers' Associations, 74-83. In addition to the use of NFA moulders, the tactics of Canada Foundry seem to have been closely modelled on the NFA plan of action.

${ }^{69}$ The Alien Labour Act permitted the importation of skilled workers under contract in restricted circumstances that likely did not apply here.

${ }^{70}$ Some of the "old world" moulders joined a protest to the provincial premier, George Ross who denied that provincial immigration agents had been involved. In addition to material in the Action File, see Labour Gazette ( $L G$ ). August 1903, 114-5 and 151-4. On organized overseas recruiting of skilled workers, see Heron and Palmer, "Prism," 453-5. 
Fond, a Toronto police constable. In addition to parrolling the area around the plant, he ran a boarding bouse established by Camada Foundry for its scab moulders.

All this surveillance, plus the arreat of three atrikers (two for loitering and one for intimidation) did not prevent some of the imported workers from quitting. "As a result, Canada Foundry sought and obtained an injunction in early September. But scab moulders continued to quit, and 20 a scheme was hatched to induce a breach of the injunction. Some of the professional strikebreakers pretended to be disgruntled Canada Foundry employees wishing to quit. When the strikers offered them assistance to leave the city. Canada Foundry brought a motion to commit for contempt. In the examinations on the affidavits that followed, the plot was revealed and the striking moulders brought a motion to commit those involved in the scheme for inducing breaches of the injunction.

The moulder's motion was heard first. Chief Justice Meredith dismissed it on the ground that no breach of the injunction had in fect occurrod. The evidence showed that the strikers had offered assistance only after the professional scabs indicated that they wished to leave. Indeed, the scabs had each signed statements before receiving money from the union stating, "This is to certify that I have of my own free will without fear of molestation or intimidation requested the moulders Union to help me out of the City." Following his reasoning in the Massey-Harris case, Meredith CJ. drew a sharp line between "inciting" an employee to leave and assisting one who had already made the decision. ${ }^{2}$

Several weeks later, Chancellor Boyd heard the employer's motion and dismissed it. In part, he relied on the equitable maxim that to get equity you must come into court with clean hands. With respect to other incidents relied upon in the motion, Boyd showed little patience for the employer's argument. "I decline to wade through the mass of papers in onder to find out what may be the residuum of all the facts, conversations, surmises, and information which has been collected from a host of witnesses." $" 73$

Even though this particular motion failed, because some superior court judges had neither the patience for employer intrigues nor the desire to act as their agents for the purpose of punishing workers, this aggressive American strategy, imported into Canada through continental employer associations, undermined the ability of unionized workers to win strikes based on their partial monopoly of skill, supple-

\footnotetext{
${ }^{71}$ It appears that none of the men were convicted and that the two men charged with loitering subsequently entered suits against Canada Foundry for assault and false imprisonment. See LG, August 1903, 152.

${ }^{72}$ Canada Foundry Co. v. Emmett (1903), 2 O.W.R. 1032. The union subsequently charged the scabs with obtaining money under false pretences. They were convicted and the money paid them was retumed to the union. Industrial Banner (IB ), October 1905, 2, col.4.

${ }^{73}$ Canada Foundry Co. v. Emmert (1903), 2 O.W.R. 1102 at 1103.
} 
mented by picketing. Despite battling their employers to a legal stalemate the moulders lost the strike against Canada Foundry.

A third component of employers' efforts to reduce the effectiveness of traditional strike tactics by skilled metal workers was a more aggressive use of the criminal law. However, for this strategy to be effective, judges had to interpret and apply the law more stringently. Not all judges were willing to do so. One legal issue was whether or not workers charged with picketing offenses were entitled to trial by jury. Some magistrates, most notably Magistrate Denison in Toronto, took the view that the accused had no right to elect trial by jury and that a magistrate could decide to proceed summarily. ${ }^{75}$ Eliminating trial by jury not only allowed employers to get criminal sanctions imposed quickly, but it also increased the chance of securing a conviction. This was because some magistrates were clearly hostile to trade union activity and because activities giving rise to criminal charges heard in the heat of a strike were more likely to be seen as serious disruptions of public order, requiring swift action. Although it is not clear whether or not Denison's interpretation of the law was widely followed, it was not until 1905 that the Code was clarified - at the urging of the Trades and Labour Congress (TLC) - to guarantee the right of the accused to elect trial by jury. ${ }^{76}$

A second issue was the scope of watching and besetting. Some lower court judges and magistrates began treating any form of picketing as the offence of watching and besetting. This conclusion was justified on the ground that the Criminal Code did not retain the express exclusion of peaceful picketing from the definition of watching and besetting that had been in the carlier legislation (and which remained in the English statutes). For example, in 1902 striking machinists in Kingston were convicted of watching and besetting and fined \$50 each simply

${ }^{74}$ The legal action dragged on until September 1905 when the union gave consent for the action to be discontinued on condition that Canada Foundry pay the legal costs of the union. IB, October 1905, 2, col.4.

${ }^{75}$ Magistrate Denison adopted this approach shortly after the Criminal Code came into force. See Tucker, "Between Two Worlds." In the Canada Foundry strike, he refused to allow the union secretary charged with intimidation a jury trial, although the case was subsequently withdrawn by the prosecution. See $L G$, August 1903, 115, 152.

${ }^{76}$ S.C. 1905. c.9. When the amendment was introduced by Mr. Guthrie, he cited the fact that the police magistrate in Toronto had, on two occasions, held that the accused did not have an unrestricted right to elect trial by jury. The ensuing debate in the House of Commons produced the following exchange:

Mr. Fitzpatrick. I think that amendment is already covered by the section, but if there is any doubt about it, as I understand there is, we should make it plain...

Mr. Bergeron. That magistrate ought to be dismissed.

Mr. Fitzpatrick. You cannot do that; be is too good a man.

See Canada, House of Commons, Debates, 13 July 1905, 9436-7. 
for unging a strikebreaker to quit and lending him $\$ 5$ to assist him to leave town." Although few watching and besetting cases reached the higher courts before the $1920 \mathrm{~s}$, trade unionists became aware of, and concerned about, the emergence of this restrictive trend. In 1900, 1901, and 1902 the TLC passed resolutions at its conventions calling for action to be taken to reverse the stricter application of the criminal law to picketing. ${ }^{7}$

The law of injunctions and the interpretation of the Criminal Code developed in tandem. After all, they regulated the same conduct and many injunctions were granted on the basis that the picketers were engaged in criminal conduct. Not surprisingly, therefore, judges disagreed as much about the scope of the criminal law prohibition as they did about the civil. Thus, for example, when metal polishers in Hamilton were charged with watching and besetting in 1900, they were acquitted baced on the comments of Meredith C.J. in the Brentford contempt motion carlier that year. "In some subsequent cases, J.G. O'Donoghue, a lawyer rethined by the TLC and who represented unions in many of the important cases of the period, successfully argued that the omission of the peaceful picketing exemption made no legal difference because initially it had been inserted simply as a matter of precaution, not because it was necessary.

Perhaps the most dramatic test of the extent of the criminal law prohibition occurred in the context of the strike of the Brantford iron moulders against the William Buck Stove Works Co. in April 1908. In the early weeks of the strike there

\#Ontario, Bureau of Labour, Annual Report (1902), 151. Also see Rex v. Metcalf, a York County General Sessions case in which a picket was convicted of persistent following. Ontario, Bureau of Labour, Annual Report (1907), 221. For some magistrates, simply calling a strikebreaker "scab" constituted criminal intimidation. For example, see Ontario, Bureau of Labour, Annual Report (1903), 178; (1906), 150 and (1907), 215.

${ }^{78}$ TLC, Proceedings, 1900-3. On developments in England and Canada focusing on the later reported cases, see Jacob Finkelman, "The Law of Picketing in Canada: I \& II," University of Toronso Law Joumal, 2 (1937-8), 67-101, 344-60.

7Hamilton Spectator (HS), 12 September 1900, 5, col.4.

${ }^{80}$ J.G. O'Donoghue was the oldest son of D.J. O'Donoghue, a prominent labour activist during the late-19th century. He graduated from law school in 1900 at the age of 29 and so was a rather inexperienced lawyer at the time he assumed the role of labour's chief litigator and legal counsel. Morgan, Canadian Men and Women and Doris French, Faith, Sweat, and Politics (Toronto 1962), passim.

${ }^{81}$ Rex.v. Bums (1903), 2 O.W.R. 1115 (County C.). For similar result see Rex v. Fraser et al, a county court judgement, noted in Ontario, Bureau of Labour, Annual Repor (1906), 211 and Rex v. Goldberg, tried at the County of York Sessions, 14 December 1906. In that case, Judge Winchester in charging the jury said, "Pickets have a right to ask men to abstain from working and to find out what is going on or to give information. There is nothing in the law to prevent that." This case and the comment were referred to in a memorandum prepared by O'Donoghue for the Executive Commituee of the TLC, dated 11 September 1917. The memorandum was published in TLC, Proceedings, (1917), 193. Judge Winchester expressed a similar view in Rex v. Medcalf, LG, November 1907, 618. 
were a number of arrests arising out of violent incidents. ${ }^{82}$ Early in May, however, 13 striking workers who were peacefully picketing were charged with watching and besetting and police magistrate Livingston committed them to trial despite the argument presented by $O^{\prime}$ Donoghue that the strikers broke no law. Moreover, the local crown attorney, Mr. Wilkes, advised the police to read the Riot Act if the picketing persisted. ${ }^{3}$ Apparently, the warning was not heeded and, although the Riot Act was not read, later that month some 60 striking workers who were peacefully picketing were issued summonses and ordered to appear before Magistrate Livingston on charges of watching and besetting. All were committed to trial at the June sessions, having elected to be tried by jury. Livingstone released the men on bail with a waming that if the picketing continued the men would be arrested, not summoned, and would be refused bail. Acting on the advice of J.G. $O$ 'Donoghue, the picketing continued the next day and nine strikers were arrested. Initially, they were denied bail, but the police magistrate subsequently backed down and the strikers were released to the cheers of a couple of hundred men assembled outside the court. ${ }^{84}$

By the time of the June sessions, nearly 100 moulders were facing charges. The grand jury returned a true bill in every case based on Judge Hardy's instructions that the law in Canada was different than in England and that even peaceful picketing to induce workers to leave their employment was contrary to the Criminal Code. ${ }^{85}$ Two test cases were then brought forward to trial. The evidence established that the men had been engaged in peaceful picketing and that there was no force or compulsion used. O'Donoghue argued for the defence that there was no case to go to the jury because Canadian law, like the English, did not prohibit this conduct. In light of his earlier comments, it was surprising that Judge Hardy granted the motion. He indicated that compulsion was an element of the offence and in the absence of evidence that the picketing was being conducted with a view to restrain men from working there was no case to go to the jury. Accordingly, the two cases were dismissed and the remainder of the charges were dropped. ${ }^{85}$

On balance, the effort to have peaceful picketing treated as a criminal offence had only limited success. The Canadian Manufacturers' Association, which may have had a hand in bringing the charges, was disappointed, but put a brave face on the outcome. It suggested that the prosecution had failed to bring forward evidence of the effect of, or motive for, the picketing and that, on a proper view, "under the

${ }^{82}$ See Brantford Courier, 21-24 April; 28-30 April; 1 \& 4 May, 1908 and LG, June 1908, 1480.

${ }^{83}$ Brantford Courier, 1 \& 4 May 1908.

${ }^{84}$ Brantford Courier, 21 \& 22 May 1908; Globe, 22 \& 23 May, 1908.

${ }^{85}$ Brantford Courier, 10 June 1908; Globe, 10 June 1908.

${ }^{86}$ Branuford Courier, 11 June 1908; Globe, 11 June 1908; LG, July 1908, 94-5. 
most peaceful circumstances the work of the picketers partakes of intimidation. This did not change the fact, however, that moet judges were simply unwilling to limit the freedom of strikers to communicate to the extent that employers' were demanding.

Despite their defensive victory, stilled warkers were still finding that their traditional supply-side strategies - withdrawing labour and picketing to discourage replacements - were becoming leas effective in disupting their employers' production. Better organized strike-breaking and the availability of injunctions and criminal prosecutions to stop any activity that hinted at compulsion or force did have an impact. Other tactics were needed and demand-side strategies, most notably boycotts, began to be pursued more vigorously than in the past. These took two forms: consumer boycouts and trades boycotts. The first conaisted of an organized campaign to convince consumers not to purchase products manufactured or supplied by employers who were "unfair" to labour, while the second involved a refusal by other trades to handle goods produced by non-union or scab labour. These strategies had been tried sporadically in Canada in the late 19th century with limited success. Employers had denounced this practice, but had not felt sufficiently threatened by it to develop or pursue a legal counter-attack. ${ }^{*}$ At the turn of the century, however, under the influence of the international unions, boycotting became more widespread in Cansda and Canadian employers, following the example of their American and English counterparts, began to turn to the courts to prevent it."

Here again, the legal path was paved by the English courts. Although there was initially a good bit of toing and froing by the courts, in the 1901 case of Quinn v. Leatham, the House of Lords unanimously held that, where such actions were motivated by an intent to injure or lacked justification, the tort of civil conspiracy was committed. ${ }^{90}$ In effect, this ruling allowed the court to scrutinize both the goals pursued and means used by trade unions. If found to be "illegitimate," the perpetrators could be held liable.

Employers and the courts were particularly hostile to actions that expanded the dispute beyond the immediate parties. Not only did this cause more economic

\footnotetext{
${ }^{87} I C$, July 1908,1107 . The decision of Judge Mather in the Winnipeg plumbers' case is promoted as the better one. The Industrial Banner (IB), August 1908, 4, col.2, in commenting on the decision, suggested that the CMA was behind the failed effort to make picketing illegal. ${ }_{88}$ Tucker, "The Faces of Coercion."

${ }^{89}$ On US developments, see Haggai Hurvitz, “American Labor Law and the Doctrine of Entrepreneurial Property Rights: Boycotts, Courts, and the Judicial Reorientation of 18861895," Industrial Relations Law Joumal, 8 (1986), 307, 328-44 and Daniel R. Ernst, "Free Labor, the Consumer Interest, and the Law of Industrial Disputes, 1885-1900," American Joumal of Legal History, 36 (1992), 19-37; on England, see Klarman, "Judges Versus the Unions," 1501-13.

90[1901] A.C. 495.
} 
damage, but the trade union was, in their eyes, inserting itself into trade relations to which it was, or should be, an outsider. This interference was unacceptable. For example, in Quinn the union was pursuing a closed shop through secondary action. and neither the goal nor the means were acceptable to the court. Closed shops interfered with the employer's right to manage and the rights of "free" labour to contract, while secondary action interfered with contractual relations between the target employer and its customers and between its customers and their employees. ${ }^{91}$

Canadian employers were quick to take advantage of English legal developments. The first employer challenge was aimed against a consumer boycott launched against the Krug Furniture Manufacturing Co. Their counsel, E.A.A. DuVernet, ${ }^{92}$ sought not only to stop interference with employees, but also with the sale of Krug's products. An interlocutory injunction was obtained and, at trial, Judge R.M. Meredith held, "'Boycotting' is, in some of its forms, very obnoxious to the law." ${ }^{.93}$ Although he did not elaborate, in the case before him he found there was some evidence of intimidation (not defined) which clearly made this boycotting tortious. A perpetual injunction was granted.

Further challenges to the legality of consumer boycotts were raised in the litigation arising out of a dispute between the Gurney Foundry $\mathrm{Co}$. and its unionized employees over alleged discrimination against union members. Gurney had a long history of conflict with unions and had broken their power in his shops in the early 1890s. Clearly, Gurney was not about to let them back in without a fight. Problems arose in January 1902 when Gurney dismissed two members of the Stovemounters International Union and twenty stovemounters struck in solidarity. Some members of the Metal Polishers' Union were subsequently let go and the other polishers also struck. By that summer, the Iron Moulders Union joined the fray. Although the strike and picketing by the unions caused some problems, Gurney was able to continue production of its stoves with non-union labour. To increase pressure on Gurney, the striking locals called for a national boycott of Gurney stoves. Locals affiliated with the striking unions brought the matter to local trades and labour councils and ultimately the boycott was endorsed by the TLC at its convention that

${ }^{91}$ On the theme of "outside" intrusion and its importance in labour law, see Karen Orren, Belated Feudalism (Cambridge 1991), 122-59.

${ }^{22}$ DuVernet's role as a labour lawyer is an interesting one. In the 1890 s he defended striking employees of the J.D. King Company charged with criminal offences. In the period under discussion, his firm defended leaders of the Cobalt Miners' strike of 1907 charged with breaching the IDIA. See Tucker, "Between Two Worlds"; O.A. RG4-32, file 1907/1393; and John D. Honsberger, "E.E.A. DuVernet, KC; Lawyer, Capitalist, 1866 to 1915," in Carol Wilton, ed., Beyond the Law: Lawyers and Business in Canada, 1830-1930 (Toronto 1990), 167-200.

${ }^{93}$ Krug Fumiture Co. v. Berlin Union No. 112 Amalgamated Woodworkers Intermational Union of America (1903), 2 O.W.R. 282. For a somewhat different report of the judgement see 5 O.L.R. 463. Quinn was cited with approval by Meredith J. in his judgement. 
September." Protests from Prince Edward Island to British Columbia were received by Gurney. In Toronto, The Toiler, a bbour paper associated with the district labour council, regularly published announcements on its front page reminding readers that Gurney Foundry, maker of Oxford stoves and ranges, are "STILL UNFAIR TO ORGANIZED LABOR" while in St. Catharines sales of Oxford stoves were 80 poor that the local vendor gave up his agency.

By August 1903, Gumey decided to begin a legal counter-offensive. DuVernet, the lawyer who had represented Krug Furniture in its action, was retained and he launched three separate actions on behalf of Gumey. First, he commenced an action against the three striking locals, the Toronto and District Labour Council, and The Toiler. In addition to damages, Gurney sought - and readily obtained an injunction to stop interference with employees and potential employees and the boycott. ${ }^{95}$ On the same day, he sued the Weatern Foundry Co. for hiring some apprentices under contract to Gurney. ${ }^{96}$ A little over two weeks later, DuVernet brought an action against various local trade union officials in St. Catharines, including the officers of the St. Catharines District Trades and Labour Council, for damages and an injunction which was granted ex parte."

The injunctions put an end to some boycott activities, like the published notices in The Toiler, but it is doubtful whether or not they had an impact on those members of the public sympathetic to the goals of labour. Moreover, The Toiler found ways to circumvent the injunction. For example, beginning in December, it ran a contest which it publicized in the same space formerly occupied by the Gurney boycott notice, inviting customers to write an essay on "WHY IS THE AD WHICH WAS IN THIS SPACE IN IT NO MORE." Then, from January to June 1904, it regularly published articles on the Gurney lawsuit, thereby reminding its readers of Gurney's hostility to organized labour.

The litigation against the union officials, now represented by J.G. O'Donoghue, the lawyer who handled most litigation for trade unions in Ontario, dragged on to no conclusive end. Aside from the fact that the injunctions were granted, no judgements were issued clarifying the boundaries of lawful behaviour. Nevertheless, the defendants in both cases agreed, as a condition of the final settlement of the actions, not to promote a boycott of Gurney's products. 9 Thus,

24or accounts of the origins of the dispute and boycott, see Gumey Foundry Co. v. Emmett, Action File 835/1903; Roberts, "Toronto Metal Workers," 66 and TLC, Proceedings, (1902).

${ }^{99}$ Gumey Foundry Co. v. Emmett, Action File 835/1903 and (1903), 2 O.W.R. 959.

${ }^{96}$ Gurney Foundry Co. v. Western Foundry Co., Action File 834/1903.

${ }^{9}$ Gumey Foundry Co. v. McGlashan, Action File 905/1903.

${ }^{98}$ The Toiler, 4 December 1903, 1, cols. 3-4.

99 The Toronto injunction case ended with a consent judgement filed in September 1905. One of the terms of the judgement was that there would be no further attempts to convince the public not to purchase Gurney's products or to advertise that their goods were unfair. The St. Catharines case dragged on until February 1907 when Gurney agreed to accept $\$ 100$ 

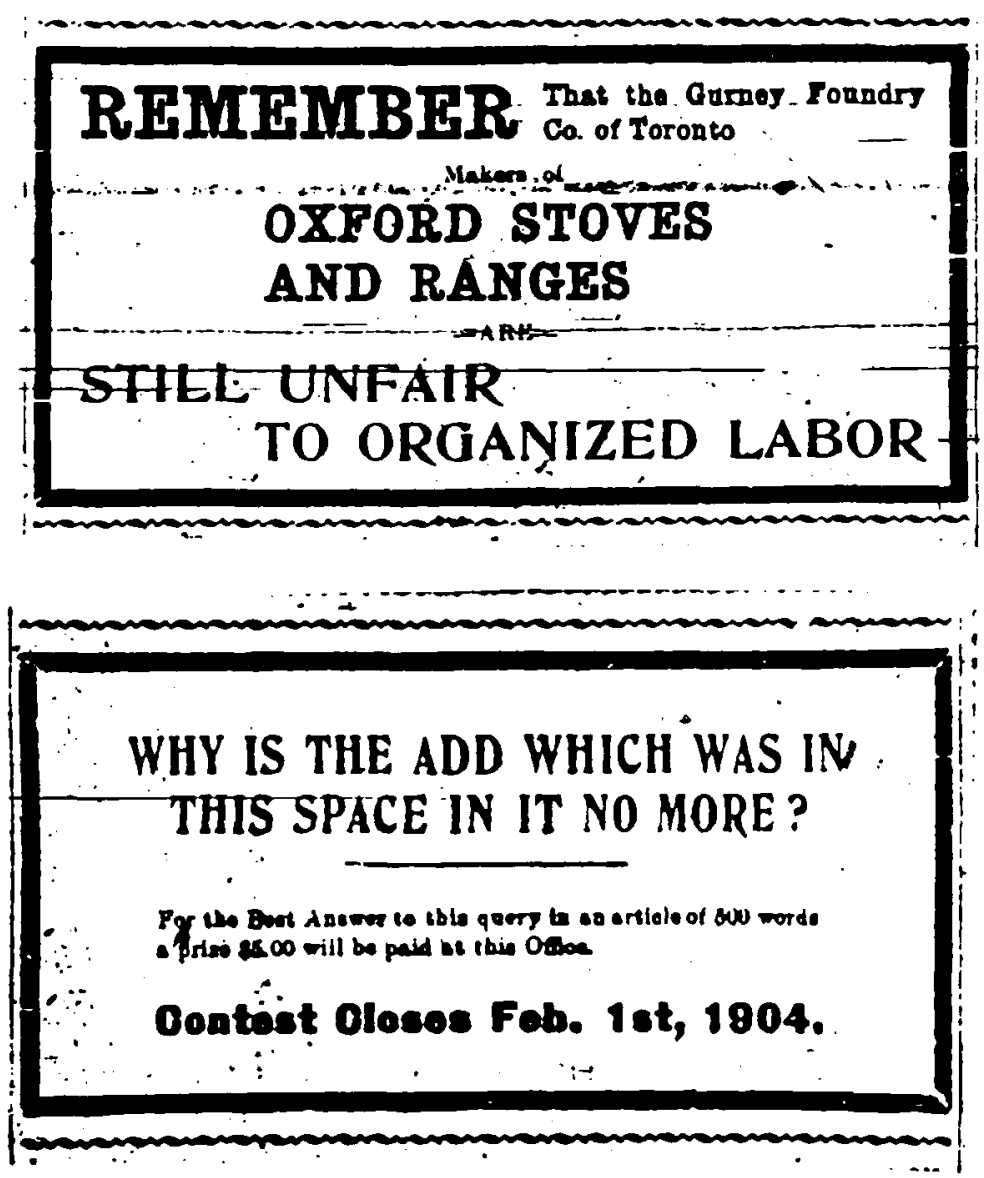

Ads in the Toiler (Toronto) before and after the injunction. The Toiler, January 30, 1903, p. 1 and December 4, 1903, p. 1 .

it would be fair to surmise that after this litigation union officials approached consumer boycotts more cautiously.

The second solidarity tactic, the refusal by unionized workers to handle materials from non-union or "unfair" firms, was challenged in perhaps the most famous litigation of the era by the Metallic Roofing Company. The dispute arose when Metallic refused to sign a contract negotiated between the Amalgamated Sheet Metal Workers' International Association, Local Union 30 and a committee of employers in the trade during the summer of 1902 . The members of the local voted overwhelmingly in favour of the contract and agreed to strike any employer

nominal damages and $\$ 100$ costs. As well, the defendants also agreed not to promote a boycott of Gurney products. 
who would not sign it. Metallic refused to sign, despite the fact that one of their managers had acted as secretary to the employed's negotiating committoc, because the agreement provided for a cloeed shop and two of the ten men it employed in the affected department were non-union. With the approval of the International, Metallic was struck. Local and international union officials expected the fight to be "short, sharp, and decisive" both because "work is plentiful and men are scarce" and because the union anticipated that it could count on other non-striking sheetmetal workers to refuse to handle Metallic's goods after they were doclared hot. It quickly became apparent, however, that this was not going to be the case. By 18 August, J.S. Chapman, reconding secretary of the local advised international headquarters, "This has become the fight of all the trades in Toronto and else where [sic] in the Dominion of Canada." 100

Metallic Roofing commenced an action for damages and an injunction. It quickly obtained an interim injunction to prevent the union from purauing the boycott and from watching and besetting. The injunction was continued by Meredith C.J. and an appeal from his docision was dismissed by the Divisional Court on the ground that a prima facie case of conspiracy to injure had been made. ${ }^{101}$ With the injunction firmly in place, two important legal issues remained outstanding. First, there was the as yet unresolved question of trade union status. Metallic had named as defendants both the local and international unions as well as various individuals. Second, was it tortious either for the union to call out its men or to notify other employers that its members would not handle Metallic's goods?

The issue of trade union status had been looming on the horizon since Massey brought its actions in 1900 , although preliminary skirmishes in those cases produced no legal precedent. The issue was crucial not in relation to injunctions, which could be framed to affect all members of a union regardless of whether or not they were parties, but for the liability of the union in damages. If judgements could only be obtained against individuals in their personal capacity, then they hardly would be worth pursuing since monetary damages would be unrecoverable in most cases. If, however, trade union funds could be made exigible, then damages not only could be recovered, but employers could attack the institutional, organizational, and financial infrastructure of their opponents. They could exert pressure on unions to be "responsible." 102

Again, developments in England paved the way for Canadian employers. The decision of the House of Lords in Taff Vale established two ways of making trade

${ }^{100}$ See correspondence between Local 30 and the International contained in Metallic Roofing Co. v. Jose, Action File 639/1902.

${ }^{101}$ Metallic Roofing Co. v. Local Union No. 30, Amalgamated Sheet Metal Workers (1903), 2O.W.R. 266.

${ }_{102}$ This was a major concern of employers. For example, see Adam Shorth, "The Incorporation of Trade Unions" IC, March 1903, 368-9 and Bliss, Living Profit, 91-2. 
unions liable. First, unions that registered under the Trade Union Act could be sued because, according to the court, this gave them legal status. Registered unions could be sued in their own name and be made liable for the authorized acts of their members. Second, individual union members could be sued in a representative capacity thereby making trade union funds liable to satisfy a judgement against them. ${ }^{103}$

From the beginning of the Metallic Roofing litigation, the question of trade union status was a crucial matter to both parties. Metallic, after all, had named the local and international unions as defendants. In February 1903 a motion was made to set aside service of a writ on an international union vice president as agent of and on behalf of the union. It was denied by the master and confirmed by Meredith J.. An appeal was subsequently allowed by Meredith $C . J$. on the ground that there was no suggestion made that trade unions in Canada had been given legal status by the legislature. He did, however, expressly leave open the possibility that a representative action might be brought. ${ }^{104}$ The plaintiffs quickly followed up this suggestion and three days later they obtained an order from Chancellor Boyd that allowed named union officials to be sued both in their personal capacities and as representatives of all union members. Further appeals and motions followed and the matter finally came before the Court of Appeal in February 1904, although a judgement was not issued until January 1905. The court held that trade unions could not be sued in their own name, since they had no legal existence, but that the plaintiff could proceed in a representative action against both the local and international union. ${ }^{105}$

With the issue of the form of the action settled (although not its implications in respect of the attachability of trade union funds), ${ }^{106}$ the case could proceed to trial on the merits. A jury trial was held in Toronto at the end of October 1905, more than three years after the action was commenced. Metallic Roofing was successful. The jury found that the plaintiffs' employees had been "wrongfully and maliciously coerced to leave its employment" by the defendants and that the defendants conspired by threats or intimidation to induce the plaintiffs' customers to refrain from dealing with them. They assessed damages at \$7,500. On the basis of these findings of fact, the trial judge, applying Quinn, awarded damages to the plaintiffs for $\$ 7,500$ and held that trade union property was liable to satisfy the judgement. As well, the injunction was made perpetual.

${ }^{103}$ Taff Vale Railway Co. v. Amalgamated Saciety of Railway Servants [1901] A.C. 426. Also see Klarman, "British Labor Law," 1521-33.

104 Metallic Roofing Co. v. Local Union No. 30 (1903), 5 O.L.R. 424.

${ }^{105}$ Metallic Roofing Co. v. Local Union No. 30 (1905), 9 O.L.R. 171. For favourable employer comment, see IC, April 1905, 556.

${ }^{106}$ Problems in this regard arose subsequently when the plaintiffs unsuccessfully sought to gamishee a bank account held to the credit of the union and three of its officers in respect of costs which had been awarded by the court of appeal. Metallic Roofing Co. v. Local Union No. 30 (1905), 10 O.L.R. 108. 
This vendict, including the surprieing finding that the trade union was an intertoper even in relations between some of its members and their employer, set off a fresh round of appeals that ultimntely led to the Juticial Committec of the Privy Council. The Ontario judges were unnimously in favour of the reault and could scarcely conceal their hotility townd the goals and means of the union in this case. Chancellor Boyd, speaking for the Divisional Court, aw this as an instance in which the union was intentionally inflicting hrm by combined action without justification, while in the Court of Appeal Meredith J.A. (formeriy C.J.) continuously referred to the union as "the foreign aseociation" and found there was ample evidence upon which the jury could have found that the union was the controlling power.

The Judicial Committee, however, allowed the appeal and sent the case back for a new trial. In doing so, however, it avoided the substance of the legal diapurte. Instead of ruling on the legality of the means used, it found there bad been a mis-direction by the trial judge which may have left the jury under the impression that calling the men out on strike by resolution was an actionable wrong in itself. ${ }^{107}$ By this time, however, the parties had had enough and they eventually agreed to dismiss the action without costs. ${ }^{100}$

What can we conclude from this episode? The Canadian Manufacturers' Association tried to put the Judicial Committoc's holding in a positive light, claiming that it in no way affected the substance of the rulings on the illegality of boycotts, but they hardly could have been pleased by the result, having contributed $\$ 9,000$ towards the costs of the litigation. ${ }^{109}$ Trade unions, for their part, also could not have taken much comfort from the result, although they too proclaimed victory. The legality of secondary trade boycotts was dubious, injunctions were just as easy to obtain as before, and the labour movement too had incurred significant legal bills in fighting the case. 110

\section{Conclusion}

IN THE COURSE of the first strike wave of the second industrial revolution, large employers of skilled metal workers sought to change the terrain on which labour relations would be conducted. Their objective was, if not to rid themselves of unions entirely, then, to make them behave responsibly. Responsible unions, as defined by employers, were to accept open shops and the use of strikebreakers and refrain from interfering with third-party economic relations by promoting boycotts

${ }^{107}$ Metallic Roofing Co. v. Jose (1906), 12 O.L.R. 200 (Div. C.); (1907), 14 O.L.R. 156 (C.A.); [1908] A.C. 514. The appellants were also awarded costs in respect of the appeals from the trial judgement.

${ }_{108}$ Action File, 639/1902; LG, March 1909, 1018.

109 IC, August 1908, 35 and Bliss, Living Profit, 92.

${ }^{110}$ For a discussion of $\pi \mathrm{C}$ reaction to this and other cases, see Craven, Impartial Umpire, 196-207. 
or engaging in sympathy strikes. ${ }^{111}$ Not coincidentally, responsible unions would be weak unions, unable to draw on communal or even strong craft solidarity. The law was an important resource for employers seeking to ensure responsible trade union behaviour. These employers not only insisted on exercising their legal privilege to maintain an open shop and to continue operating with replacement workers during strikes, but they also claimed a legally protected right to do so without interference from unionized workers. This right was asserted in the courts through civil actions for injunctions and damages and prosecutions under the criminal law.

Legal strategies were attractive for two interrelated reasons. First, legal victories were enforceable through direct state coercion. Workers who violated courtapproved rights' claims were liable in damages to "injured" employers or, in the case of criminal transgressions, could be arrested and imprisoned. Police officers or other law enforcement personnel could be deployed to protect the property of employers and to enable the employer to operate with replacement workers. Second, the production of legal discourse that embraced employers' ideals of free labour and freedom of contract could have ideological effects. The judicial elevation of what were previously privileges to rights could enhance the legitimacy of the more restrictive institutional arrangements employers hoped to establish.

How successful were employers in achieving their institutional and ideological objectives? Measured in strictly legal terms, employers achieved substantial institutional victories. Many of their rights' claims were accepted by the judges. Consumer boycotts and refusals by workers in other locations to handle struck or non-union work were characterized as tortious interference. Inducing replacement workers to breach their contracts of employment by, for example, offering to find them alternative work, was also wrongful. Furthermore, it was beyond doubt that workers could not trespass on the employers' property or create a nuisance. ${ }^{112}$ Once established as legal rights, injunctions could be issued and damages claimed against individual workers and trade union officials personally, ${ }^{113}$ and unions through representative actions. On the criminal side, physical coercion, threats, and intimidation were clearly prohibited; so too was picketing if there was evidence that striking workers intended to prevent other workers from taking their places.

Although the number of civil actions and criminal prosecutions was not large in proportion to the number of strikes during this period, the TLC took these ${ }^{111}$ For a useful expression of this agenda, see IC, September 1907, 97-9.

${ }^{112}$ For example, a representative of striking plumbers in Toronto who went on to an employer's premises to convince the plumbers employed there to join the strike was convicted of trespass and fined thirty dollars by the magistrate who, in sentencing the defendant, said: "I am going to stop this sort of thing." $L G$, November 1907, 617-8.

${ }^{113}$ For example, in Brauch v. Roth (1904), 10 O.L.R. 284, an official of the bricklayers and masons' union was sued for inducing breach of contract by calling members of the union off a job because the foundation had been laid by non-union labour. Damages of $\$ 50$ were awarded. 
developments seriously. ${ }^{114}$ They, too, recognized the strategic importance of the restrictions the law was plecing on their freedom of action. Not only were numerous resolutions pased cosdemning the boetile atriude of the judiciary toward trade unions, but the $\pi \mathrm{C}$ lobbied for anti-injunction legislation and for changes to the criminal law. It also retained J.G. O'Donoghve as its lawyer to fight important cases. ${ }^{115}$ On the political front, only in British Columbia did the campaign for anti-injunction legislation succeed, and the Criminal Code was amended only to clarify that workers accused of watching and besetting had the right to elect trial by jury. ${ }^{116}$

In the courts, watkers conteated the employers' legal offensive and partially blunted its effectiveness. Their lawyers were able to convince most judges that the employers' right to froedom of contract should not be extended to override the privilege of atriking workers to communicate with non-striking workers. In most instances, judges refued to enjoin, or convict worters for, peaceful picketing. On the question of trade union stutus, most judges would not recognize the union as a separate legal entity, although representative actions could achieve a similar result. Union lawyers were less successful in convincing judges that the closed shop was a lawful objective or that boycotts and sympathy strikes were lawful means. Even relatively sympathetic judges like William Meredith rejected these claims. Yet, when union members and officials committed unlawful acts, their lawyers leamed to take advantage of procedural and technical niceties to avoid liability. Most civil actions ended in a stalemate, though employers won some important legal points. Damages were rarely awarded and there were formidable obstacles to collecting on judgements. These were important defensive victories. Reflecting back on this period in 1917, when faced with a new rash of injunctions in Manitoba, J.G. O'Donoghue wrote: "Some years ago in Ontario injunctions were largely resorted to in Labor [sic] disputes, but by constant hard fighting in the Courts (a very expensive process) the Judges eventually hesitated somewhat about granting injunctions in such extensive terms as appear in the recent Winnipeg injunctions." 117

Lawyers met with less success defending workers charged with criminal offenses. Charges were frequently tried by magistrates and lower court judges who, aside from their personal sympathies, were concerned to put an immediate end to ongoing disonder and violence, which was almost always occasioned by the use of

114 To date, we have discovered only 19 Canadian strikes between 1900 and 1914 in which injunctions were issued (see Appendix 1). There were over 2400 strikes in this period. See Douglas Cruikshank and Gregory S. Kealey, "Strikes in Canada, 1891-1950," Labour/Le Travail, 20 (1987), 85-145. The number of strikes with criminal charges against workers is less certain, but our data suggests that criminal charges were at least twice as frequent.

${ }_{115}$ Craven, Impartial Umpire, $200-7$.

${ }^{116}$ Carrothers, "A Legislative History," 341-4 and references in supra, note 45.

${ }^{117}$ See TLC, Proceedings, (1917), 193. 
strikebreakers. ${ }^{118}$ This resulted in convictions, often with little concern for legal niceties. J.G. O'Donoghue, for example, while defending striking garment workers in Toronto, complained to a County Court Judge about the Toronto Police Court: "I would not let a man take a charge over there at all. The strikers get the short end of it all the time." 119

Trade union lawyers also endeavoured to use the legal process offensively. In the Gurney litigation, O'Donoghue cross-examined W.C. Gurney on his affidavit at great length and, when Gurney refused to produce some documents and answer some questions, he brought a motion to have Gurney committed to jail for contempt. In the Canada Foundry dispute, the union obtained information about the employer's strikebreaking activities and challenged the legality of their intrigues. As well, a picket who was arrested and subsequently acquitted brought an action for false arrest and imprisonment, while a strikebreaker who quit his employment brought a charge in police court against the company when it withheld his tools. ${ }^{120}$ In at least two instances, trade unions challenged the legality of an employer blacklist on the grounds that it constituted a civil or criminal conspiracy to injure. ${ }^{121}$ The Vancouver Trades and Labor Council successfully obtained an injunction to prevent a construction company from breaching its contract with them by using non-union labour in the construction of the new Labour Temple. ${ }^{122}$ Strikebreakers and detectives were occasionally charged for their violent actions, but there were numerous complaints about the failure of the police and the courts to protect striking workers from their provocations. ${ }^{123}$

${ }^{118}$ Deputy Magistrate Kingsford, in defending himself against a Toronto Trades and Labor Council complaint of bias for convicting a worker and fining him \$20, stated: "The friends of the strikers were giving a great deal of trouble and unless checked would have gone on and the peace of the city would have been endangered. A heavy fine was necessary and I imposed it without hesitation." Letter from R.E. Kingsford to J.R. Cartwright, Deputy A.G., 16 July 1900 , in AO, RG4-32, File 1900/1034.

${ }^{119}$ Toronto Telegram, 22 September 1913, clipping in National Archives of Canada (NAC), RG27, Vol. 301, Strike 48. The protest of the Toronto TLC to the Premier about Deputy Magistrate Kingsford, ibid, is one of many such complaints.

${ }^{120}$ Gumey Foundry Co. v. Emmett (1903), 2 O.W.R. 1038; LG, September 1903, 267; February 1905, 917. Another unsuccessful action for false imprisonment was later brought by a machinist. See Plant v, Jones \& Moore Electric Co., LG, March 1908, 1159-60 (Ont. S.C.). ${ }^{121}$ Mitchell v. Woods (1906), 4 W.L.R. 371 (B.C.S.C.) (civil conspiracy); R. v. Employers' Association, LG, February 1907, 927 (criminal, police courh Toronto).

122 James Conley, "'Open Shop' Means Closed to Union Men": Cappenters and the 1911 Vancouver Trades General Strike," BC Studies, 91-2 (1991-92), 127-51 at 143.

${ }^{123}$ For example, a private prosecution was launched against a detective who shot and wounded a person who claimed to be a by-stander during a strike-related riot in Owen Sound, Ont. in May 1908. See AO, RG4-32, File 1908/653. Thiel Agency detectives who shot into a crowd wounding three strikers during a strike of gold miners in South Porcupine, Ont. were convicted of unlawfully shooting with intent to cause bodily harm and fined $\$ 100$. See 
The use of injunctions againat skilled worken declined after the 1900-1903 strike wave. ${ }^{124}$ It is more difficult to eseess chenges in the incidence of the use of criminal sanctions, ${ }^{125}$ but any decline in the use of direct state coencion by employers should not be attributed exclusively to workers' successful resistance in the courts. Skilled worters also altered their tactics to reduce their exposure to civil actions and criminal prosecution. For exumple, consumer boycouts and other forms of secondary action were used leas frequently in the strike waves of 1907-8 and 1912-13.

Observance of legal rules, however, does not necesuarily signify acceptance of their normativity. The fear of incurring anctions may be sufficient to induce strategic compliance. How successful, then, was the employers' legal strategy in achieving their ideological objectives? Of course, the employing class did not need to be convinced of the legitimacy of their claims, 00 their legal institutionalization, at best, may have helped confirm them in their beliefs and made it easier for them to justify to themselves the application of coercion. However, the more significant question is the ideological impect of legal discourse on those less predisposed to sccept the law's wond.

The absence of direct evidence of what most people believed (or how those beliefs were shaped) dictates caution in addressing this question. Skilled unionized metal workers, the immediate targets of this form of legal coercion, probably did not feel they were wrongdoers, but rather the victims of a system that systematically favoured their employers. Moreover, unionized workers never sccepted the legitimacy of "scab" labour, despite judicial thetoric defending its use on the grounds of individual freedom. Not only were striking workers prepared verbally to intimidate, but picket-line violence against replacement workers leading to criminal charges was not uncommon. Ilegal boycotts and sympathy strikes became less frequent, but such actions generally required a higher degree of organization than spontaneous acts of defiance. Craft-union officials, concerned about the institutional consequences of lawbreaking and their personal liability, were loath to

NAC, RG27, Vol. 300, Strike 3618. In Smith Falls, Ont, a strikebreaker was convicted on a firearms offence during a strike in 1914 by the Iron Moulders' Union against the Malleable Castings Co. His fine of $\$ 1$ drew protests. See AO, RG4-32, File 1914/1914. In the 1914 ILGWU strike against Dominion Cloak, fifteen strikers faced charges, but so too did two strikebreakers and two private detectives. J.G. O'Donoghue complained that the charge of disonderly conduct and the fine of \$S did not reflect the seriousness of the strikebreakers' misconduct. He was also refused warrants when he complained about other assaults by strikebreakers, while strikers were arrested in the same incident. See NAC, RG27, Vol. 303, Strike 9.

124 Ten of the nineteen injunctions were obtained between 1900 and 1903. Nine of these were against skilled workers in southem Ontario. See Appendix 1.

${ }^{125}$ Our incomplete data suggests criminal charges were as likely to be brought against unskilled as skilled workers and that there was greater use of criminal law in the period from 1906-08 than during the strike waves of 1899-1903 and 1912-13. 
provide the necessary leadership, but that should not be mistaken for acceptance in principle of the right to trade by union leaders or the membership.

The impact of this legal discourse on other segments of the public is even harder to gauge. There is no evidence of popular expression of opinion on the courts' decisions in the metal workers' strikes. The campaign to boycott Gurney stoves seems to have been successful enough to cause Gurney to take legal action, but consumer response to the judicial declaration that the boycott was illegal is unknown. Some evidence from other contexts suggests widespread hostility to the use of scab labour in many communities. For example, attempts by street railways to operate with scab labour frequently provoked a violent response from people in the affected community. ${ }^{126}$ In Buckingham, Quebec, a coroners' jury examining deaths that occurred during a riot triggered by an attempt to run lumber mills with strikebreakers recommended that the men responsible for bringing them in should face criminal prosecution in addition to those who directly caused the deaths. ${ }^{127}$ Perhaps the most that can be said is that the imprimatur of law was sufficient to produce the passive assent by significant numbers of people to the imposition of restrictions on trade union activity, but that workers and their immediate communities were less impressed. Overall, we suggest the industrial relations regime was weakly hegemonic.

All of these conclusions, however, must be qualified by a reminder that we have only considered one component of a broader transformation of labour relations, their institutionalization and public representation. Skilled male craft workers constituted a minority of the workforce and employers were increasingly able to expose their organizational weaknesses and take advantage of them. Industrial workers employed in sectors deemed to be central to the national economy were becoming a greater concern to state and business elites. Although their goals were often similar (for example, strike prevention, and responsible unionism), different institutional responses, including compulsory conciliation and massive use of state coercion, became a prominent feature of industrial conflict in those sectors. Any overall assessment of the institutionalization of labour relations, including both its coercive and ideological effectiveness, must take into account this broader picture.

The legal changes examined here, however, are of abiding significance, even in regimes of statutory collective bargaining. Although the law now allows unions to demand a closed shop, boycotts and sympathy strikes are forbidden, and even more effective sanctions have been developed to punish workers and their unions for engaging in such conduct. ${ }^{128}$ As well, picket-line conduct is carefully moni-

${ }^{126}$ There was rioting and other forms of violence during street railway strikes in Toronto (1902), Montreal (1903), Winnipeg (1906), Hamilton (1906), Halifax (1913), Port Arthur and Fort William (1913), and St. John, N.B. (1914). (Source: $L G$ ).

${ }^{127}$ LG, November 1906, 556-8.

${ }^{128}$ See, for example, A.W.R. Carrothers, et al., Collective Bargaining Law in Canada, $2 d$ ed., (Toronto 1986). 
tored, injunctions are still readily available and criminal charges are still common. In short, pragmatic acceptance of judicinlly conanucted and enforced labour laws, let alone normative acceptance, is as tenuous as ever.

The authors would like to thank Chris Tomlins, Greg Kealey, Reuben Hasson, and four anonymous LIT reviewers for their constructive comments on an earlier version of this article, originally presented at the North American Labor History Conference, Wayne State University, Detroit, October 27-29, 1994.

Research for this article was funded by a grant from the Social Sciences and Humanities Research Council whose support is gratefully acknowledged. 


\section{Appendix 1}

Labour Injunctions in Canada, 1900-1914

(Preliminary List)

\begin{tabular}{|c|c|c|c|}
\hline \multicolumn{2}{|c|}{ Na. Year, City, Province } & \multirow{2}{*}{$\frac{\text { Employer }}{\text { Massey-Harris }}$} & \multirow{2}{*}{$\begin{array}{l}\text { Union } \\
\text { Iron Moulders Union }\end{array}$} \\
\hline 1 & 1900 , Toronto, ON & & \\
\hline 2 & 1900, Brantford, ON & Masscy-Harris & Iron Moulders Union \\
\hline 3 & 1901, Rossland, BC & LeRoi Mining Co. et al. & Western Foderation of Miners \\
\hline 4 & 1902, Toronto, ON & Gurney Foundry & Iron Moulders Union et al. \\
\hline 5 & 1902, Toronto, ON & Metallic Roofing & $\begin{array}{l}\text { Amalgamated Sheet Metal } \\
\text { Workers Union }\end{array}$ \\
\hline 6 & 1902, Berlin, ON & Krug Furniture & $\begin{array}{l}\text { Amalgamated Woodworkers' Int' } 1 \text {. } \\
\text { Union }\end{array}$ \\
\hline 7 & 1902, London, ON & Grand Opera & American Federation of Musicians \\
\hline 8 & 1903, Toronto, ON & Dixon Carriage Works & Carriage Makers' Union \\
\hline 9 & 1903, Toronto, ON & Canada Foundry & Iron Moulders Union \\
\hline 10 & 1903, Berlin, ON & Brauch (contractor) & Bricklayers' and Masons' Union \\
\hline 11 & 1905, Stratford, ON & Grand Trunk Railway & Int'l. Assoc. of Machinists et al. \\
\hline 12 & 1905, Toronto, ON & Hough Lithographing & Lithographers' Union \\
\hline 13 & 1906, Winnipeg, MB & Vulcan Iron Works & Int'1. Assoc. of Machinists et al. \\
\hline 14 & 1906, Port Arthur, ON & Canada Foundry & Int'l. Iron Workers Union \\
\hline 15 & 1906, Winnipeg, MB & Master plumbers & Journeymen Plumbers et al. Union \\
\hline 16 & 1907. Cobalt, ON & Silver Mines & Westem Federation of Mines \\
\hline 17 & 1909, Springhill, NS & Cumberland Railway & United Mineworkers of America \\
\hline 18 & 1909, Glace Bay, NS & Dominion Coal & United Mineworkers of America \\
\hline 19 & 1913, Winnipeg, MB & Morley \& Sons et al. & Painters and Decorators Union \\
\hline
\end{tabular}

(Principal source: $L G$ ) 